\title{
Chapter 20 \\ Economics of Land Degradation and Improvement in Tanzania and Malawi
}

\author{
Oliver K. Kirui
}

\begin{abstract}
Land degradation is a serious impediment to improving rural livelihoods in Tanzania and Malawi. This paper identifies major land degradation patterns and causes, and analyzes the determinants of soil erosion and sustainable land management (SLM) in these two countries. The results show that land degradation hotspots cover about 51 and $41 \%$ of the terrestrial areas in Tanzania and Malawi, respectively. The analysis of nationally representative household surveys shows that the key drivers of SLM in these countries are biophysical, demographic, regional and socio-economic determinants. Secure land tenure, access to markets and extension services are major factors incentivizing SLM adoption. The implications of this study are that policies and strategies that facilitate secure land tenure and access to SLM information are likely to stimulate investments in SLM. Local institutions providing credit services, inputs such as seed and fertilizers, and extension services must be included in the development policies. Following a Total Economic Value approach, we find that the annual cost of land degradation due to land use and land cover change during the 2001-2009 period is about \$244 million in Malawi and \$2.3 billion in Tanzania (expressed in constant 2007 USD). These represent about 6.8 and $13.7 \%$ of GDP in Malawi and Tanzania, respectively. Use of land degrading practices in croplands (maize, rice and wheat) resulted in losses amounting to \$5.7 million in Malawi and \$1.8 million in Tanzania. Consequently, we conclude that the costs of action against land degradation are lower than the costs of inaction by about 4.3 times in Malawi and 3.8 times in Tanzania over the 30 year horizon. This implies that a dollar spent to restore/rehabilitate degraded lands returns about 4.3 dollars in Malawi and 3.8 dollars in Tanzania, respectively. Some of the actions taken by communities to address the loss of ecosystem services or enhance or maintain ecosystem services improvement include afforestation programs, enacting of bylaws to protect existing forests, area closures and controlled grazing, community sanctions for overgrazing, and integrated soil fertility management in croplands.
\end{abstract}

\footnotetext{
O.K. Kirui ( $₫)$

Center for Development Research (ZEF), University of Bonn, Walter-Flex Street 3, 53113 Bonn, Germany

e-mail: okirui@uni-bonn.de; oliverkk@yahoo.com 
Keywords Economics of land degradation - Causes of land degradation Sustainable land management $\cdot$ Cost of land degradation - Tanzania $\cdot$ Malawi

\section{Introduction}

Land degradation is a major problem in Tanzania and Malawi. A recent assessment shows that 'land degradation hotspots' cover about 51 and $41 \%$ of land area in Tanzania and Malawi, respectively (Le et al. 2014; Fig. 20.1). Figure 20.1 shows a depiction of land degradation and improvement 'hotspots' in Africa. ${ }^{1}$ A country-specific hotspot map for Malawi and Tanzania is also presented alongside the African map. In Tanzania, land degradation has been ranked as the top environmental problem for more than 60 years (Assey et al. 2007). Soil erosion is reportedly affecting about $61 \%$ of the entire land area in this country (ibid). Chemical land degradation, including soil pollution and salinization/alkalinisation, has led to $15 \%$ loss in the arable land in Malawi in the last decade alone (Chabala et al. 2012).

Investments in sustainable land management (SLM) are an economically sensible way to address land degradation (MEA 2005; Akhtar-Schuster et al. 2011; FAO 2011; ELD Initiative 2013). SLM, also referred to as 'ecosystem approach', ensures long-term conservation of the productive capacity of lands and the sustainable use of natural ecosystems. However, available estimates show that the adoption of SLM practices in sub-Saharan Africa, including Tanzania and Malawi, is low-just on about $3 \%$ of total cropland (WB 2010). Several factors limit the adoption of SLM in the region, including: lack of local-level capacities, knowledge gaps on specific land degradation and SLM issues, poor monitoring and evaluation of land degradation and its accompanying impacts, inappropriate incentive structure (such as, inappropriate land tenure and user rights), market and infrastructure constraints (such as, insecure prices of agricultural products, increasing input costs, inaccessible markets), and policy and institutional bottlenecks (such as, difficulty and costly enforcement of existing laws that favor SLM) (Thompson et al. 2009; Chasek et al. 2011; Akhtar-Schuster et al. 2011; Reed et al. 2011; ELD Initiative 2013).

Despite on-going land degradation and the urgent need for action to prevent and reverse land degradation, the problem has yet to be appropriately addressed, especially in the developing countries, including in Tanzania and Malawi. Adequately strong policy action for SLM is missing, and a coherent and evidence-based policy framework addressing it is still lacking (Nkonya et al. 2013). Identifying drivers of land degradation and the determinants of SLM adoption is a step towards addressing them (von Braun et al. 2012).

The assessment of relevant drivers of land degradation by robust techniques at farm level is still lacking in Tanzania and Malawi. There is a need for evidence-based economic evaluations, using more data and robust economic tools,

\footnotetext{
${ }^{1}$ See Chap. 4 of this volume for a global 'hotspots' maps.
} 


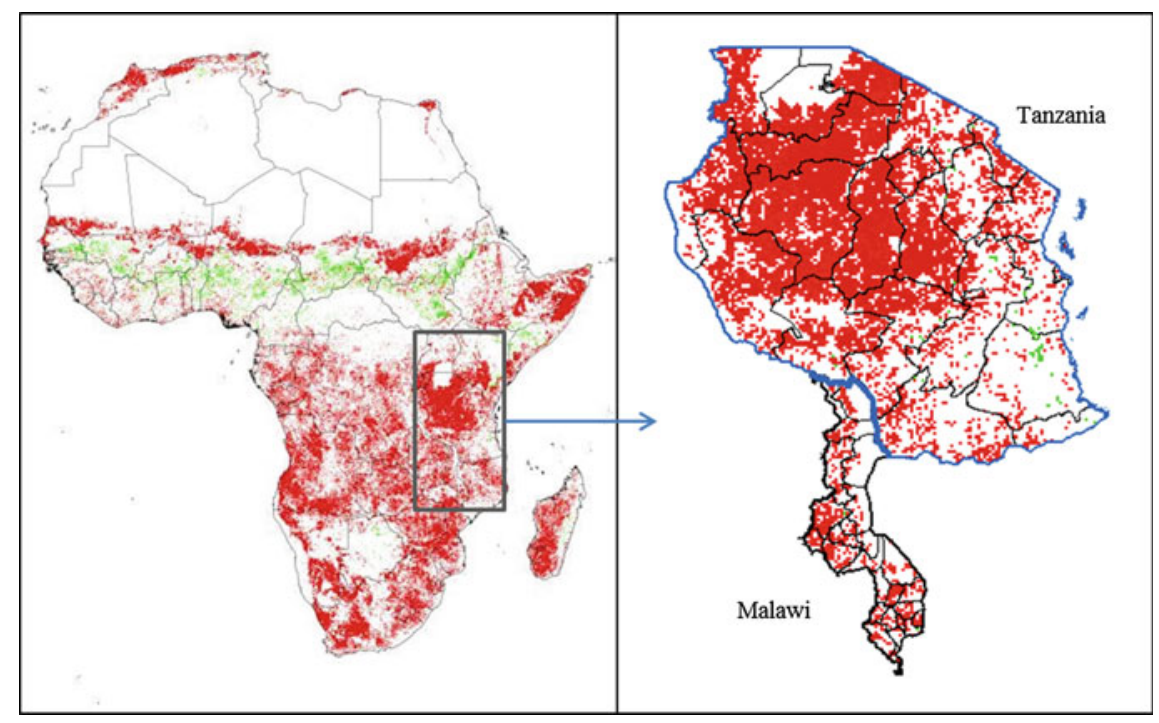

Fig. 20.1 Biomass productivity decline (Note The geographic spread of the area subject to human-induced degradation processes among the different climatic zones of SSA and selected countries in Eastern Africa. The red spots show the pixels with significantly declining NDVI while the green spots show the pixels with significantly improving NDVI.) in Malawi and Tanzania for 1982-2006. Source Adapted from Le et al. (2014)

to identify the determinants of adoption as well as economic returns from SLM. The objectives of this paper are thus two-fold; (i) to assess the determinants of SLM adoption in Malawi and Tanzania, and (ii) to examine the costs and benefits of action versus of inaction against land degradation in Malawi and Tanzania.

The rest of this paper is organized as follows: see section "Relevant Literature" provides a brief review of key studies on the extent, drivers of land degradation and determinants of SLM adoption in Tanzania and Malawi; see section "Land Management Policy Frameworks in Malawi and Tanzania" presents the policy frameworks in Malawi and Tanzania; see section "Conceptual Framework and Empirical Strategy" presents the study methods and the empirical strategy; see section "Data, Sampling Procedure and Variables for Estimations" outlines the data, study area and sampling procedure; see section "Results and Discussions" discusses the findings of the study; see section "Conclusions and Policy Implications" concludes.

\section{Relevant Literature}

Drivers of land degradation can be grouped into two categories, namely; proximate and underlying causes (Lambin and Geist 2006; Lal and Stewart 2010; Belay et al. 2014; Pingali et al. 2014). Proximate causes are those that have a direct effect on the 
terrestrial ecosystem. These include biophysical (natural) conditions related to climatic conditions and extreme weather events such as droughts and coastal surges.

Key proximate drivers include; climatic conditions, topography, unsuitable land uses and inappropriate land management practices (such as slash and burn agriculture, timber and charcoal extraction, deforestation, overgrazing) and uncontrolled fires. The dry aid and semi-arid arid lands are prone to fires which may lead to serious soil erosion (Voortman et al. 2000; D'Odorico et al. 2013). The erratic rainfall in these areas may also be thought to induce salinization of the soil (Safriel and Adeel 2005; Wale and Dejenie 2013). Similarly, practicing unsustainable agriculture such as land clearing, overstocking of herds, charcoal and wood extraction, cultivation on steep slopes, bush burning, pollution of land and water sources, and soil nutrient mining (Eswaran et al. 2001; Lal 1995; Dregne 2002). Most deforestation exercises are associated with the continued demand for agricultural land, fuel-wood, charcoal, construction materials, large-scale and resettlement of people in forested areas. This often happens at the backdrop of ineffective institutional mechanisms to preserve forests. Grazing pressure and reduction of the tree cover continue to diminish rangelands productivity (Hein and de Ridder 2006; Waters et al. 2013).

Important underlying drivers of land degradation include land tenure, poverty, population density and weak policy and regulatory environment in the agricultural and environmental sectors (Table 20.1). Insecure land tenure may act as a disincentive to investment in sustainable agricultural practices and Technologies (Kabubo-Mariara 2007). Similarly, a growing population without proper land management will exhaust the capacity of land to provide ecosystem services (Tiffen et al. 1994). It is also argued that population pressure leads to expansion of agriculture into fragile areas and reduction of fallow periods in the cultivated plots.

Table 20.1 Empirical review of proximate and underlying causes of land degradation

\begin{tabular}{|c|c|c|c|}
\hline Country & Proximate drivers & Underlying drivers & References \\
\hline Malawi & $\begin{array}{l}\text { Charcoal and wood fuel } \\
\text { (for domestic and } \\
\text { commercial), timber } \\
\text { production; } \\
\text { unsustainable agric. } \\
\text { Methods (slash and burn } \\
\text { with shorter rotations), } \\
\text { mining }\end{array}$ & $\begin{array}{l}\text { Development processes } \\
\text { in energy, forestry, } \\
\text { agriculture and water } \\
\text { sectors; poverty; lack of } \\
\text { alternative energy } \\
\text { sources; weak policy } \\
\text { environment, lack of } \\
\text { planning; insecure land } \\
\text { tenure }\end{array}$ & $\begin{array}{l}\text { Pender et al. (2004a), } \\
\text { Lambin and Meyfroidt } \\
\text { (2010), Rademaekers } \\
\text { et al. (2010), Kiage } \\
\text { (2013), Thierfelder et al. } \\
\text { (2013), Harris et al. } \\
\text { (2014) }\end{array}$ \\
\hline Tanzania & $\begin{array}{l}\text { Topography, climate } \\
\text { change, settlement and } \\
\text { agricultural expansion, } \\
\text { overgrazing, fuelwood } \\
\text { and timber extraction, } \\
\text { uncontrolled fires }\end{array}$ & $\begin{array}{l}\text { Market and institutional } \\
\text { failures, rapid } \\
\text { population growth, rural } \\
\text { poverty, insecure } \\
\text { tenure, and absence of } \\
\text { land use planning, } \\
\text { development of } \\
\text { infrastructure }\end{array}$ & $\begin{array}{l}\text { Pender et al. (2004b), de } \\
\text { Fries et al. (2010), } \\
\text { Fisher et al. (2010), } \\
\text { Wasige et al. (2013), } \\
\text { Ligonja and Shrestha } \\
\text { (2013), Heckmann } \\
\text { (2014) }\end{array}$ \\
\hline
\end{tabular}

Source Kirui and Mirzabaev (2014) 
However, this is not always the case. Population pressure has been found to increase agricultural intensification and higher land productivity as well as technological and institutional innovation that reduce natural resource degradation (Tiffen et al. 1994; Nkonya et al. 2008).

Empirical review of literature on adoption of production-related technologies dates back to Feder et al. (1985) which summarizes that the adoption of new technology may be constrained by many factors such as lack of credit, inadequate and unstable supply of complementary inputs, uncertainty and risks. A comprehensive review of literature shows several factors determining investment in sustainable land management practices. These include; household and farm characteristics, technology attributes, perception of land degradation problem, profitability of the technology/practice, institutional factors, such as, land tenure, access to credit, information and markets and risks and uncertainty (Ervin and Ervin 1982; Norris and Batie 1987; Pagiola 1996; Shiferaw and Holden 1998; Kazianga and Masters 2002; Shively 2001; Bamire et al. 2002; Barrett et al. 2001; Gebremedhin and Swinton 2003; Habron 2004; Kim et al. 2005; Park and Lohr 2005; Pender et al. 2006; Gillespie et al. 2007; Prokopy et al. 2008).

Detailed empirical studies in developing countries include that of Pagiola (1996) in Kenya, Nakhumwa and Hassan (2012) in Malawi, Shiferaw and Holden (1998), Gebremedhin and Swinton (2003) and Bekele and Drake (2003) in Ethiopia. All these studies highlighted the direction as well as the magnitude of factors hypothesized to condition the adoption of SLM.

In summary, these factors are largely area specific and their importance is varied between and within agro-ecological zones and across countries. Thus, caution should be exercised in attempting to generalize such individual constraints across regions and countries.

Important contributions have been made by these previous studies on identifying the determinants of adoption of SLM practices, however, a number of limitations are evident. Despite the fact that a long list of explanatory variables is used, most of the statistical estimations used by these studies have lower explanatory power (Ghadim and Pannell 1999). The results from different studies are often contradictory regarding any given variable (ibid).

Lindner (1987) and Ghadim et al. (2005) point out that the inconsistency results in most empirical studies could be explained by four shortcomings, namely; poorly specified models, inability to account for the dynamic adoption learning process, omitted variable biases, and poorly related hypotheses to the conceptual frameworks.

\section{Land Management Policy Frameworks in Malawi and Tanzania}

To counter the challenges of low input use, rising food and fertilizer prices, fertilizer subsidies have become a common policy response to increase fertilizer use and improve food production. Use of inorganic fertilizer is considered one of the 
agricultural technologies that have the potential to increase productivity of small-scale agriculture, increase incomes, expand assets base of the poor farmers and break the poverty cycle. In recent years Malawi and Tanzania have used subsidies in order to increase fertilizer application at farm level. Subsequently, there has been a substantial increase in public investment reported in the subsidies in these countries. Malawi, for instance, used about $72 \%$ of the agricultural budget in 2008/09 period on the subsidies (Dorward and Chirwa 2009) while Tanzania spent about $50 \%$ of its agricultural budget on the subsidy program (URT 2008; cited from Marenya et al. 2012).

At the end of the 1990s, there was widespread perception in Malawi that reduction in fertilizer subsidies was leading to falling in the production of maize and thus to a food and political crisis (Chinsinga 2008). In response the government of Malawi implemented three programs of fertilizer subsidies: the Starter Pack (SP), the Targeted Input Program (TIP) (later changed to the Extended Targeted Input program-ETIP), and the Agricultural Input Subsidy Program (AISP). The AISP program was launched in 1998 and was mainly supported by the UK Department for International Development (DFID) (Chinsinga 2008). The program targeted an estimated 2.86 million rural farming households and consisted of delivering free inputs to these farmers. The package consisted of $15 \mathrm{~kg}$ of fertilizer, $2 \mathrm{~kg}$ of hybrid maize seed, and $1 \mathrm{~kg}$ legume seed (Morris et al. 2007; Chinsinga 2008; Levy and Barahona 2002).

The second program implemented was the Targeted Input Program (TIP). TIP was introduced during the 2000-2001 growing season as a gradual exit strategy decided to scale down the SP and for purposes of sustainability with a target of 1.5 million farmers (Chinsinga 2008). Moreover, it also delivered a smaller quantity of fertilizer $(10 \mathrm{~kg})$ per beneficiary, replaced hybrid maize seeds with OPV maize seeds (which were considered more sustainable), and targeted the poorest households in the community (Levy and Barahona 2002). Later TIP was phased out and reconfigured as the Extended Targeted Input program (ETIP) with increased number of targeted beneficiaries of 2.8 million farmers and increased the provision of fertilizer to $26 \mathrm{~kg}$ and seeds to $5 \mathrm{~kg}$ per beneficiary. This third and much larger fertilizer subsidy program was the Agricultural Input Subsidy Program (AISP) and started in 2005. The AISP provided about $50 \%$ of farm households (around 1.5 million of households) with $100 \mathrm{~kg}$ fertilizer vouchers and smaller quantities of maize seed. Since 2005 , the program has been repeated on a similar scale, enabling beneficiaries to purchase the same amounts of fertilizer (Denning et al. 2009).

Following the successes of the input subsidy program in Malawi in terms of higher crop productivity, other countries, namely Tanzania, have also started a voucher-based fertilizer subsidies program named National Agricultural Input Voucher System (NAIVS) (URT 2005). With NAIVS the Tanzanian government used to subsidize ensured delivery of fertilizer to remote areas. The program was redesigned in 2008 into a voucher-based subsidy. This subsidy involved delivery of $100 \mathrm{~kg}$ of fertilizer, seeds, seedlings, and agrochemicals. These were exchangeable at any private agro-input dealer across the country. In this respect, the Tanzania voucher program is considered more successful in enhancing and facilitating the 
development of a private distribution network (Zorya 2009; Minot and Benson 2009). NAIVS the subsidy program is progressive type of transfer that targets the smallholder farmers. It covers a large fraction of agricultural households -2.5 million in 2011. The program design includes rationing with a set a ceiling of subsidized volumes per beneficiary of 1 acre and is geared towards staple crops, primarily maize. The subsidy program focus is on national and also household food security and explicitly includes poverty reduction in its objectives (Zorya 2009).

The other alternative that can be considered as an alternative to straight subsidies is the payments for environmental services (PES) model. The State of Food and Agriculture 2007 published by FAO (2007) highlighted the potential of PES in agriculture to contribute to the provision of ecosystem services that are not usually tradeable in the market. Future studies must explore the contributions of the PES options to soil fertility management (Marenya et al. 2012).

\section{Conceptual Framework and Empirical Strategy}

The conceptual framework used in this study broadly follows the ELD framework presented in Nkonya et al. (2013). 'The causes of land degradation are divided into two broad categories; proximate and underlying causes, which interact with each other to result in different levels of land degradation. The level of land degradation determines its outcomes or effects - whether on-site or off-site, on the provision of ecosystem services and the benefits humans derive from those services. Actors (including land users, policy makers etc.) can then take action to control the causes of land degradation, its level, or its effects'. 'There also exists institutional arrangements that determine whether actors choose to act against land degradation and whether the level or type of action undertaken will effectively reduce or halt land degradation' (Nkonya et al. 2013). For a comprehensive discussion on the conceptual framework, refer to Chap. 2 of this volume.

\section{Empirical Strategy}

\section{Determinants of SLM Adoption: Logit Regression Model}

Land degradation occurs as a result of lack of use of SLM. The determinants inhibiting the adoption of SLM practices are also possible to promote land degradation. The assessment of the determinants of SLM has the same implications as the assessment of the determinants of land degradation. The adoption of SLM technologies/practices in this study refers to use of one or more SLM technologies in a given plot. The adoption was of SLM technology/practice in a farm plot was measured as a binary dummy variable $(1=$ adopted SLM in a farm plot, $0=$ otherwise). The two appropriate methods to estimate such binary dummy 
dependent variable regression models are the logit and the probit regression models. Here, we used the logit model.

The reduced form of the logit model applied to nationally representative agricultural household survey data from Tanzania and Malawi is presented as:

$$
\mathrm{A}=\boldsymbol{\beta}_{0}+\boldsymbol{\beta}_{1} \boldsymbol{x}_{1}+\boldsymbol{\beta}_{2} \boldsymbol{x}_{2}+\boldsymbol{\beta}_{3} \boldsymbol{x}_{3}+\boldsymbol{\beta}_{4} \boldsymbol{x}_{4}+\boldsymbol{\beta}_{5} z_{i}+\boldsymbol{\varepsilon}_{i}
$$

where, $\mathrm{A}=$ Adoption of SLM technologies; $\mathrm{x}_{1}=\mathrm{a}$ vector of biophysical factors (climate conditions, agro-ecological zones); $\mathrm{x}_{2}=\mathrm{a}$ vector of demographic characteristics factors (age, gender, and level of education of the household head); $\mathrm{x}_{3}=\mathrm{a}$ vector of farm-level variables (access to extension, market access, distance to market, distance to market); $\mathrm{x}_{4}=$ vector of socio-economic and institutional characteristics (access to extension, market access, land tenure, land tenure); $z_{i}=$ vector of country fixed effects; and $\varepsilon_{i}$ is the error term.

Adoption studies using dichotomous adoption decisions models have inherent weakness (Dimara and Skuras 2003). The single stage decision making process characterized by a dichotomous adoption decision models is a direct consequence of the full information assumption entrenched in the definition of adoption, that is, individual adoption is defined as 'the degree of use of a technology in the long run equilibrium when the farmer has full information about the new technology and its potential' (Dimara and Skuras 2003). This assumption of full information is usually violated and hence use of logit or probit models in modeling adoption decision may lead to model misspecification. Robust checks tare carried out to check these misspecifications. Further, assessment beyond adoption to intensity (number) of SLM adoption can also counter such inherent weakness. We explore this option in our study.

\section{Determinants of Number of SLM Technologies Adopted: Poisson Regression Model}

The number of SLM technologies and the corresponding proportion of plots in which these technologies were applied are as presented in Table 20.8. The number of SLM technologies is thus a count variable (ranging from 0 to 6 in our case). Thus the assessment of the determinants number of SLM technologies adopted requires models that accounts for count variables. Poisson regression model (PRM) is typically the initial step for most count data analyses (Areal et al. 2008). PRM is preferred because it takes considers the non-negative and binary nature of the data (Winkelmann and Zimmermann 1995). The assumption of equality of the variance and conditional mean in PRM also accounts for the inherent heteroscedasticity and skewed distribution of nonnegative data (ibid). PRM is further preferred because the log-linear model allows for treatment of zeros (ibid). The reduced form of the Poisson regression is presented as follows: 


$$
\mathrm{A}=\boldsymbol{\beta}_{0}+\boldsymbol{\beta}_{1} \boldsymbol{x}_{1}+\boldsymbol{\beta}_{2} \boldsymbol{x}_{2}+\boldsymbol{\beta}_{3} \boldsymbol{x}_{3}+\boldsymbol{\beta}_{4} \boldsymbol{x}_{4}+\boldsymbol{\beta}_{5} z_{i}+\boldsymbol{\varepsilon}_{i}
$$

where, $\mathrm{A}=$ Number of SLM technologies adopted; and the vector of explanatory variables xi are similar to those used in Eq. 20.1; (i.e. $\mathrm{x} 1=\mathrm{a}$ vector of biophysical factors (climate conditions, agro-ecological zones); $\mathrm{x} 2=$ a vector of demographic characteristics factors (level of education, age, gender of the household head); $\mathrm{x} 3=\mathrm{a}$ vector of farm-level variables (access to extension, market access, distance to market, distance to market); $\mathrm{x} 4=$ vector of socio-economic and institutional characteristics (access to extension, market access, land tenure, land tenure); $\mathrm{zi}=$ vector of country fixed effects; and $\varepsilon_{i}$ is the error term).

Some of the limitations of PRM in empirical work relates to the restrictions imposed by the model on the conditional mean and the variance of the dependent variable. This violation leads to under-dispersion or over-dispersion. Overdispersion refers to excess variation when the systematic structure of the model is correct (Berk 2007). Overdispersion means that to variance of the coefficient estimates are larger than anticipated mean - which results in inefficient, potentially biased parameter estimates and spuriously small standard errors (Xiang and Lee 2005). Under dispersion on the other hand refers to a situation in which the variance of the dependent is less than its conditional mean. In presence of under- or over-dispersion, though still consistent, the estimates of the PRM are inefficient and biased and may lead to misleading inference (Famoye et al. 2005; Greene 2012). Our tests showed no evidence of under- or over-dispersion. Moreover, the conditional mean of the distribution of SLM technologies was similar to the conditional variance. Thus PRM was appropriately applied.

\section{Cost of Action Verses Inaction Against Degradation}

This study utilizes the Total Economic Value (TEV) approach-that captures the comprehensive definition of land degradation to estimate the costs of land degradation. TEV is broadly sub-divided into two categories; use and non-use values. The use value comprises of direct and indirect use. The direct use includes marketed outputs involving priced consumption (such as crop production, fisheries, tourism) as well as un-priced benefits (such as local culture and recreation value). The indirect use value consists of un-priced ecosystem functions such as water purification, carbon sequestration among others. The non-use value is divided into three categories namely; bequest, altruistic and existence values. All these three benefits are un-priced. In between these two major categories, there is the option value, which includes both marketable outputs and ecosystem services for future direct or indirect use. TEV analytical approach, thus, assigns value to both tradable and non-tradable ecosystem services. 
Refer to Chaps. 2 and 6 of this volume for a comprehensive discussion on the empirical strategy to estimate the costs of land degradation (due to LUCC and due to use of land degrading practices in croplands and rangelands) and also the empirical strategy to estimate the costs of taking action against land degradation.

\section{Data, Sampling Procedure and Variables for Estimations}

\section{Data and Sampling Procedure}

The data used for this study is based on household surveys in two countries; Malawi and Tanzania conducted over time periods. The surveys were supported by the Living Standards Measurement Study-Integrated Surveys on Agriculture (LSMS-ISA) project undertaken by the Development Research Group at the World Bank. ${ }^{2}$ The surveys under the LSMS-ISA project are modeled on the multi-topic integrated household survey design of the LSMS; household, agriculture, and community questionnaires, are each an integral part of every survey. We describe the sampling procedure in each of the two countries below.

\section{Tanzania}

The 2010-2011 Tanzania National Panel Survey data was collected during a twelve-month period from September 2010 to September 2011 by the Tanzania National Bureau of Statistics (NBS). In order to produce nationally representative statistics, the TNPS is based on a stratified multi-stage cluster sample design. The sampling frame used the National Master Sample Frame (2002 Population and Housing Census) which is a list of all populated enumeration areas in the country. 'In the first stage stratification was done along two dimensions; (i) eight administrative zones (seven on Mainland Tanzania plus Zanzibar as an eighth zone), and (ii) rural versus urban clusters within each administrative zone. The combination of these two dimensions yields 16 strata. Within each stratum, clusters were then randomly selected as the primary sampling units, with the probability of selection proportional to their population size'. In rural areas a cluster was defined as an entire village while in urban areas a cluster was defined as a census enumeration area (2002 Population and Housing Census). In the last stage, 8 households were randomly chosen in each cluster. Overall, 409 clusters and 3924 households (6038 farm plots) were selected.

\footnotetext{
${ }^{2}$ Funded by the Bill and Melinda Gates Foundation.
} 
Fig. 20.2 Distribution of sampled households. Source Authors

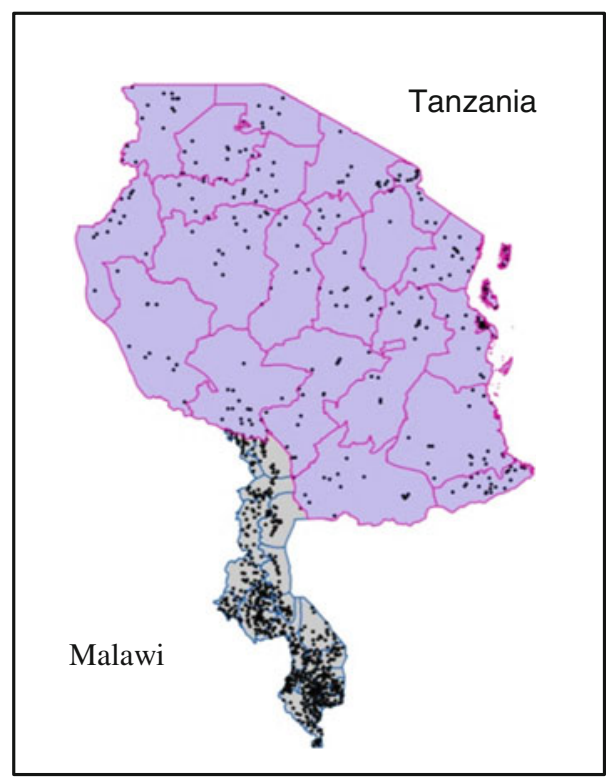

\section{Malawi}

The Malawi 2010-2011 Integrated Household Survey (IHS) is a national-wide survey collected during the period March 2010-March 2011 by the National Statistics Office (NSO). The sampling frame for the IHS is based on the listing information from the 2008 Malawi Population and Housing Census. The IHS followed a stratified two-stage sample design. The first stage involved selection of the primary sampling units following proportionate to size sampling procedure. These include the census enumerations areas (EAs) defined for the 2008 Malawi Population and Housing Census. An enumerations area was the smallest operational area established for the census with well-defined boundaries and with an average of about 235 households. A total of 768 EAs (average of 24 EAs in each of the 31 districts) were selected across the country. In the second stage, 16 households were randomly selected for interviews in each EA. In total 12,271 households (18,329 farm plots) were interviewed. The distribution of this representative data is also depicted in Fig. 20.2.

\section{Variables Used in the Econometric Estimations}

\section{Dependent Variables}

In the empirical estimation of the determinants of adoption of SLM practices, the dependent variable is the choice of SLM option(s) from the set of SLM practices 
Table 20.2 Dependent variables

\begin{tabular}{l|l|l|l}
\hline Variable & $\begin{array}{l}\text { Malawi } \\
(\mathrm{n}=18,162)\end{array}$ & $\begin{array}{l}\text { Tanzania } \\
(\mathrm{n}=5614)\end{array}$ & $\begin{array}{l}\text { Total } \\
(\mathrm{n}=239,776)\end{array}$ \\
\hline \multicolumn{4}{|l}{ Adoption of SLM practices (\% of plots) } \\
\hline \multicolumn{1}{l}{ Inorganic fertilizers use } & 63.6 & 12.4 & 46.7 \\
\hline Modern seeds varieties & 58.0 & 24.4 & 36.0 \\
\hline Manure application & 10.6 & 8.6 & 15.3 \\
\hline Intercropping & 35.1 & 32.5 & 34.8 \\
\hline Crop rotation & 10.6 & 14.8 & 23.5 \\
\hline Soil erosion control & 41.0 & 8.6 & 22.4 \\
\hline $\begin{array}{l}\text { Used at least one SLM } \\
\text { practice }\end{array}$ & 89.4 & 68.5 & 84.5 \\
\hline
\end{tabular}

Source Authors' compilation

applied in the farm plots as enumerated by the respondents. The list of the specific SLM practices is also presented in Table 20.2. They include six practices namely; soil and water conservation measures (especially those aimed at soil erosion control), manure application, modern crop seeds, inorganic fertilizers application, crop rotation (cereal-legume), and intercropping (cereal-legume).

Soil-water conservation practices include soil erosion conservation measures such as terraces, grass strips and gabions. They also include tillage practices that entail minimized soil disturbance (reduced tillage, zero tillage) and crop residue retention for better improved soil fertility and soil aeration (Delgado et al. 2011; Triboi and Triboi-Blondel 2014; Teklewold et al. 2013). Crop rotation and intercropping systems are considered as temporal diversifications aimed at maintaining farm productivity (Deressa et al. 2009; Kassie et al. 2013; Lin and Chen 2014). The application of manure (farm yard and/or animal manure) on the farm plots aids the long-term maintenance of soil fertility and supply of nutrients in the soil (Diacono and Montemurro 2010; Shakeel et al. 2014). The use of modern seed varieties and inorganic fertilizers (NPK) has the potential to spur productivity and hence improving the household food security situation and income (Asfaw et al. 2012; Folberth et al. 2013).

We considered six SLM practices. In organic fertilizers were applied in about $47 \%$ of the plots while improved seed varieties were used in about $36 \%$ of the plots. Manure use is low-average of $15 \%$ of the plots. Crop rotation and cereal-legume intercropping was practiced in about 24 and $35 \%$ of the plots respectively. Soil erosion control measure comprising of soil bunds, stone bunds terraces, plant barriers and check dams were used in about $22 \%$ of the plots. The variations in application of these practices are presented in Table 20.2. 


\section{Independent Variables}

The choice of relevant explanatory variables is based on economic theory, empirical review of previous literature, and data availability. Thus, we have utilized a total of 29 variables for the empirical estimations in this chapter. These can be grouped as biophysical, demographic, plot, and socio-economic variables. Brief descriptions alongside the direction of the hypothesized effects of these variables on land degradation and on SLM adoption are presented in Table 20.3 and discussed below.

The relevant biophysical variables included are temperature, rainfall, soil properties (rooting condition) and agro-ecological zonal classification. Adequate and timely rainfall, optimal temperature and favorable soil conditions are some of

Table 20.3 Definitions of hypothesized explanatory variables

\begin{tabular}{|c|c|c|}
\hline Variable & Definition & $\begin{array}{l}\text { Hypothesized effect on SLM } \\
\text { adoption }\end{array}$ \\
\hline Temperature & Annual mean temperature $\left({ }^{\circ} \mathrm{C}\right)$ & $+1-$ \\
\hline Rainfall & Annual mean rainfall $(\mathrm{mm})$ & $+1-$ \\
\hline Land cover & Land cover type & $+/-$ \\
\hline Elevation & The plot altitude & $+1-$ \\
\hline Soils quality & Soil rooting conditions & $+1-$ \\
\hline Soil type & The type of soil in the plot & \\
\hline aez & Agro-ecological zone & $+/-$ \\
\hline Slope & Slope elevation (SRTM) & $+1-$ \\
\hline Age & Age of household head (years) & $+1-$ \\
\hline Gender & Gender of household head & + \\
\hline Education & $\begin{array}{l}\text { Years of formal education of } \mathrm{HH} \\
\text { head }\end{array}$ & + \\
\hline Family size & Size of household (adult equivalent) & $+1-$ \\
\hline Plot slope & Slope of the plot (SRTM) & + \\
\hline Tenure & Land tenure status of the plot & + \\
\hline Soil type & Soil type of the plot & $+1-$ \\
\hline Extension & Access to agricultural extension & $+1-$ \\
\hline Home distance & $\begin{array}{l}\text { Distance to plot from the farmer's } \\
\text { home }\end{array}$ & - \\
\hline Market distance & Distance from plot from the market & - \\
\hline Assets value & Value of household assets & + \\
\hline Plot size & Size of the plot & + \\
\hline Credit access & Access to credit accessed & + \\
\hline Credit amount & Amount of credit accessed & + \\
\hline $\begin{array}{l}\text { Group } \\
\text { membership }\end{array}$ & $\begin{array}{l}\text { Membership in } \\
\text { cooperatives/SACCOs }\end{array}$ & + \\
\hline Irrigation & Access to irrigation water & + \\
\hline
\end{tabular}

Source Authors' compilation 
the biophysical factors needed for agricultural production to thrive. Favorable rainfall, temperature and soil conditions are hypothesized to positively influence adoption of improved seed varieties and use of fertilizers (Belay and Bewket 2013; Kassie et al. 2013). On the contrary, inadequate rainfall, increasing temperatures are thus hypothesized to positively influence the adoption of such SLM practices as conservation tillage, use of manure and intercropping (Yu et al. 2008). High rainfall is hypothesized to negatively influence adoption of such SLM as conservation tillage practices because it may encourage weed growth and also cause water logging (Jansen et al. 2006).

Our analyses also include such standard household level variables as age, gender, and education level of the household head and household size (adult equivalent) and household size. Household demographic characteristics have been found to affect the adoption of SLM practices (Pender and Gebremedhin 2008; Bluffstone and Köhlin 2011; Belay and Bewket 2013; Kassie et al. 2013; Genius et al. 2014). We hypothesize that higher level of education of the household decision maker/head is associated with adoption of SLM practices and technologies. Previous studies show a positive relationship between the education level of the household decision maker and the adoption of improved technologies and land management (Maddison 2006; Marenya and Barrett 2007; Kassie et al. 2011; Arslan et al. 2013; Teklewold et al. 2013). Households with more education may have greater access to productivity enhancing inputs as a result of access to non-farm income (Kassie et al. 2011). Such households may also be more aware of the benefits of SLM strategies due to their ability to search, decode and apply new information and knowledge pertaining SLM (Kassie et al. 2011; Kirui and Njiraini 2013).

The hypothesized effect of age on SLM adoption is thus indeterminate. Gender of the household decision maker plays a critical role in SLM adoption. Existing cultural and social setups that dictate access to and control over farm resources (especially land) and other external inputs (fertilizer and seeds) are deemed to discriminate against women (de Groote and Coulibaly 1998; Gebreselassie et al. 2013).We thus hypothesize that male-headed households are more likely to invest in land conservation measures than their counterparts. Household size may affect SLM adoption in two ways; larger household sizes may be associated with higher labor endowment, thus, in peak times such households are not limited with labor supply requirement and are more likely to adopt SLM practices (Burger and Zaal 2012; Belay and Bewket 2013; Kassie et al. 2013). On the other hand, higher consumption pressure occasioned by increased household size may lead to diversion of labor to non-farm/off-farm activities (Yirga 2007; Pender and Gebremedhin 2008; Fentie et al. 2013).

Relevant plot level characteristics identified from previous literature that determine SLM adoption include; plot tenure, plot size, and distance from the plot to the markets. Distance from the plot to market represents the transaction costs related to output and input markets, availability of information, financial and credit organizations, and technology accessibility. Previous studies do not find a consistent relationship between market access and land degradation. Good access to markets is 
associated with increased opportunity costs of labor as a result of benefits accrued from alternative opportunities; thus discouraging the adoption of labor-intensive SLM practices such as conservation farming (von Braun et al. 2012). However, better market access may act as an incentive to land users to invest in SLM practices because of a reduction in transaction costs of access to inputs such as improved seed and fertilizers (Pender et al. 2006) and improved access to output markets (von Braun et al. 2012). We hypothesize that the further away the plot is from markets, the smaller the likelihood of adoption of new seed varieties and fertilizers. However, we hypothesize also that the further away the plot is from the markets the bigger the likelihood of adoption of alternative SLM practices such as conservation farming, crop rotation and manure application.

\section{Results and Discussions}

\section{Descriptive Statistics of the Independent Variables}

We discuss the results of the descriptive analysis on this section. Table 20.4 presents the results of the mean and standard deviation of all the independent variables used in the regression models. Results show substantial differences in the mean values of the biophysical, demographic, plot-level, and socioeconomic characteristics by country (Table 20.4).

Among the biophysical characteristics, notable differences are reported in such variables as mean annual rainfall, elevation and agro-ecological classification. For example, the mean annual rainfall ranged from as low as $1080 \mathrm{~mm}$ per annum in Malawi to as high as $1227 \mathrm{~mm}$ per annum in Tanzania; with the average for the two countries being about $1085 \mathrm{~mm}$ per annum. Regarding elevation, the average plot elevation for the region was $900 \mathrm{~m}$ above sea level. This was not much varied between the two countries. The mean value of plot elevation in Malawi was $890 \mathrm{~m}$ above sea level but as high as $931 \mathrm{~mm}$ above sea level in Tanzania.

Similarly considerable differences is notable across countries with regards to agro-ecological classification; a larger proportion (46\%) of Malawi is classified as warm arid/semiarid, while in Tanzania a bigger proportion $(55 \%)$ is classified as warm humid/sub-humid environment.

Regarding demographic characteristics, no considerable change was reported with regard to such variables as average age of the household head (45 years) and average family size (4.3 adults). However, there seems to be a marginal difference in the education level of the household head; as low as about 2.7 years in Malawi and as high as 4.9 years in Tanzania. The households were predominantly male-head; $78 \%$ in Malawi, and $79 \%$ in Tanzania.

Plot characteristics also differed by country. For instance, ownership of the plots (possession of a plot title-deed) was least in Tanzania (11\%) but higher in Malawi (79 \%). On average, distance from the farm plot to the farmer's house was closer in 


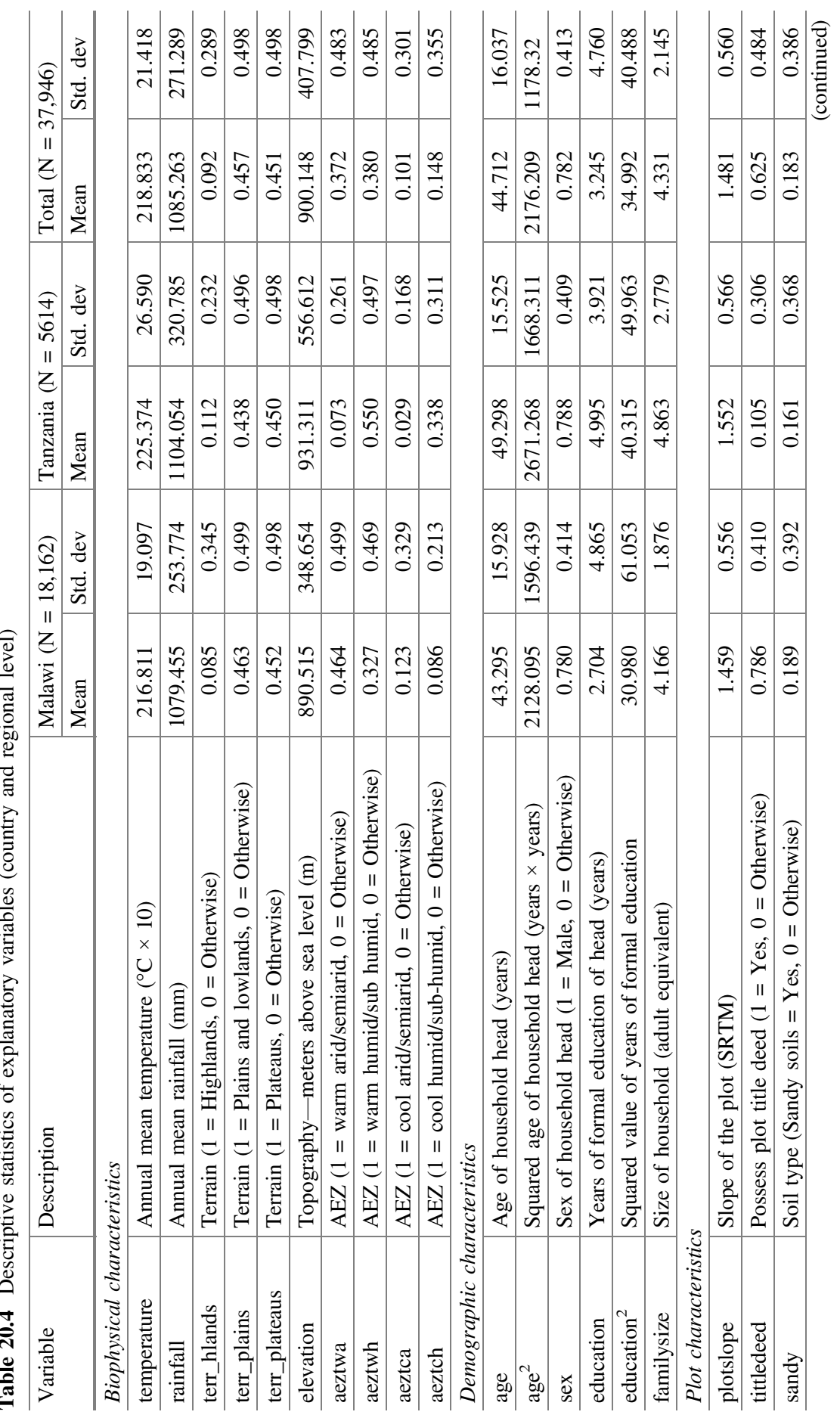




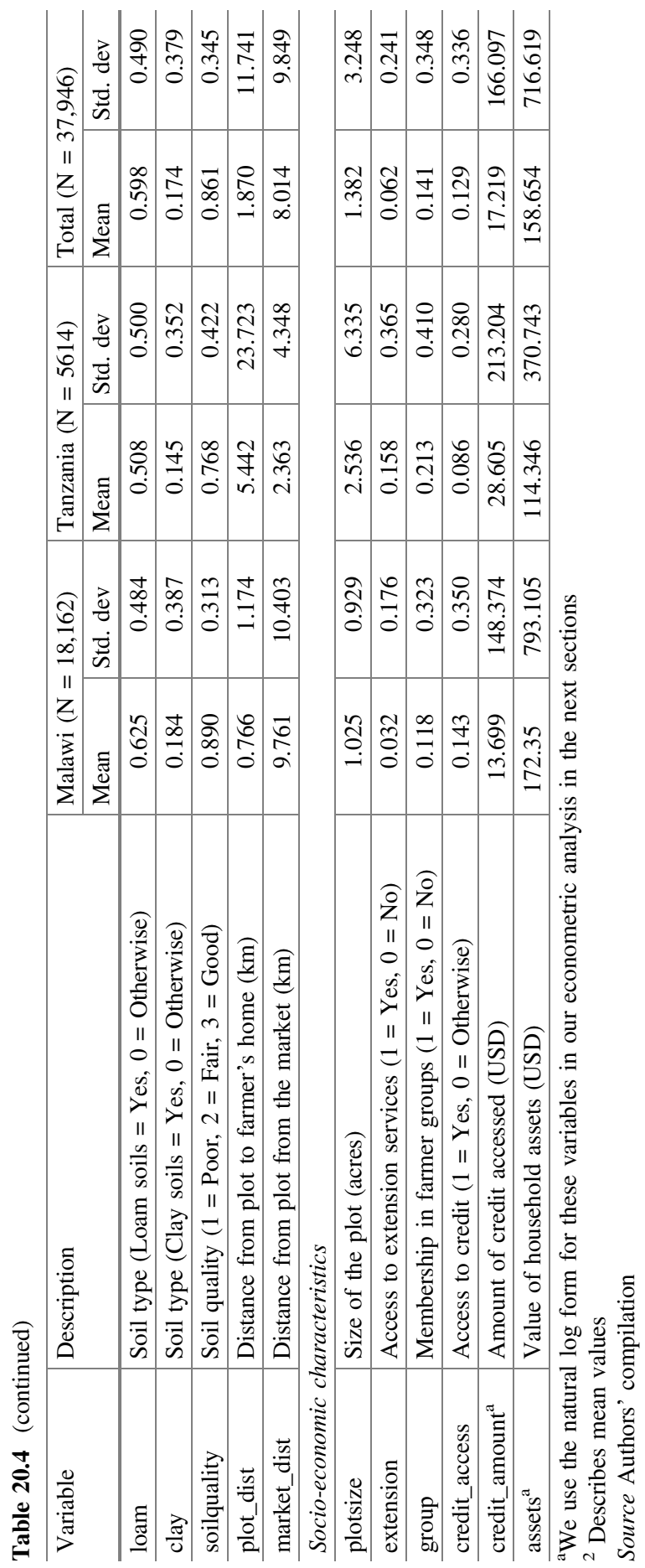


Malawi $(0.8 \mathrm{~km})$ as compared to Tanzania $(5.4 \mathrm{~km})$. Similarly, the distance to the market from the plots varied substantially between the two countries; from $2.4 \mathrm{~km}$ in Tanzania to about $10 \mathrm{~km}$ in Malawi. Loam soils were predominant soil type in both Malawi (63\% of plots) and Tanzania (50\% of the plots).

The average size of the plots was 1.4 acres. This ranged from an average of 1.0 acre in Malawi to 2.5 acres in Tanzania. About $18 \%$ of the sampled farmers were involved in social capital formation as shown by participation in collective action groups (farmer groups and cooperatives). The average proportion of sampled farmers with access to credit financial services was $13 \%$ (ranging from as low as $9 \%$ in Tanzania to $14 \%$ in Malawi). The average household assets were about 158 USD. This varied substantially by country-171 USD in Malawi and 114 USD in Tanzania.

\section{Adoption of SLM Technologies/Practices}

We examine the proportion of plots that adopted at least one SLM practice in Fig. 20.3. Results indicate that about $85 \%$ of plots were under at least one of the six SLM practices. This was varied across countries ranging from $68 \%$ in Tanzania to $89 \%$ in Malawi.

We also present the proportion of plots in which the various SLM practices/technologies were used in Fig. 20.4. Overall, inorganic fertilizers, improved seeds, manure application was used in about 51, 32 and $10 \%$ of the farm plots. Intercropping, crop rotation and use of soil erosion control measure were applied in about 35, 14 and $33 \%$ respectively. The adoptions of these technologies/practices were varied between the two countries. For example, the use of inorganic fertilizers was highest in Malawi (64 \%) and lowest in Tanzania (12\%). Improved seeds were used in about $34 \%$ of the plots in Malawi and in about $24 \%$ of plots in Tanzania.

The application of manure was quite low; about $11 \%$ in Malawi and $9 \%$ in Tanzania. Intercropping was similar in both countries; about $35 \%$ of plots in Malawi and about $32 \%$ in Tanzania. Crop rotation was practiced in about $12 \%$ of plots in Malawi and about $15 \%$ of plots in Tanzania. The use of soil erosion control measures ranged from $9 \%$ in Tanzania to $41 \%$ in Malawi.

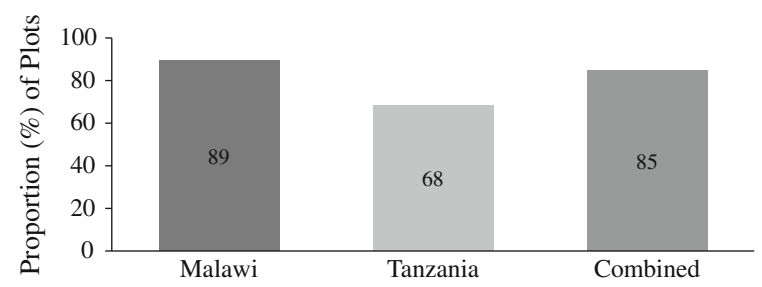

Fig. 20.3 The adoption of SLM technologies in Malawi and Tanzania. Source Authors' compilation 


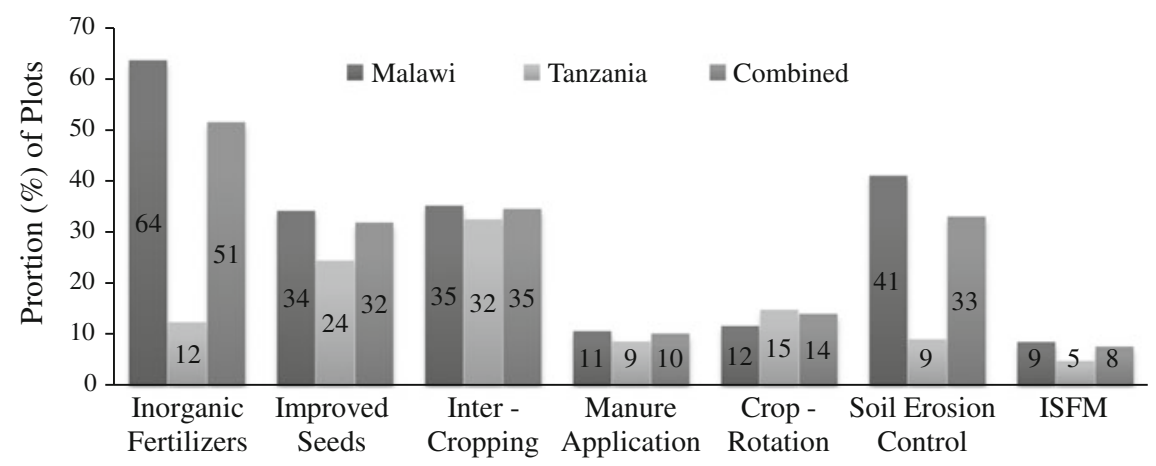

Fig. 20.4 The distribution of different SLM technologies adopted in Malawi and Tanzania. Source Authors' compilation

We also assessed the adoption of Integrated Soil Fertility Management (ISFM) practices (use of inorganic fertilizers and organic inputs) in the case study countries. Overall, ISFM was used in about $8 \%$ of plots (about $9 \%$ in Malawi and only $5 \%$ in Tanzania). We further present the distribution of the number of SLM practices/technologies used in farm plots in Fig. 20.5. The distribution ranged from 0 to 6 . On average, about $16 \%$ of the surveyed households did not apply any SLM technologies in their farm plots in the two countries. About 33, 28 and $18 \%$ applied 1,2 , and 3 technologies respectively. While about 5 and $1 \%$ applied 4 and 5 technologies respectively.

At country-level, 11 and $32 \%$ of the plots were not under any SLM technology in Malawi and Tanzania respectively. Further, our assessments show the proportion of plots with only one SLM technology was about 29 and $45 \%$ in Malawi and Tanzania respectively. Similarly, two SLM technologies were applied in about 32

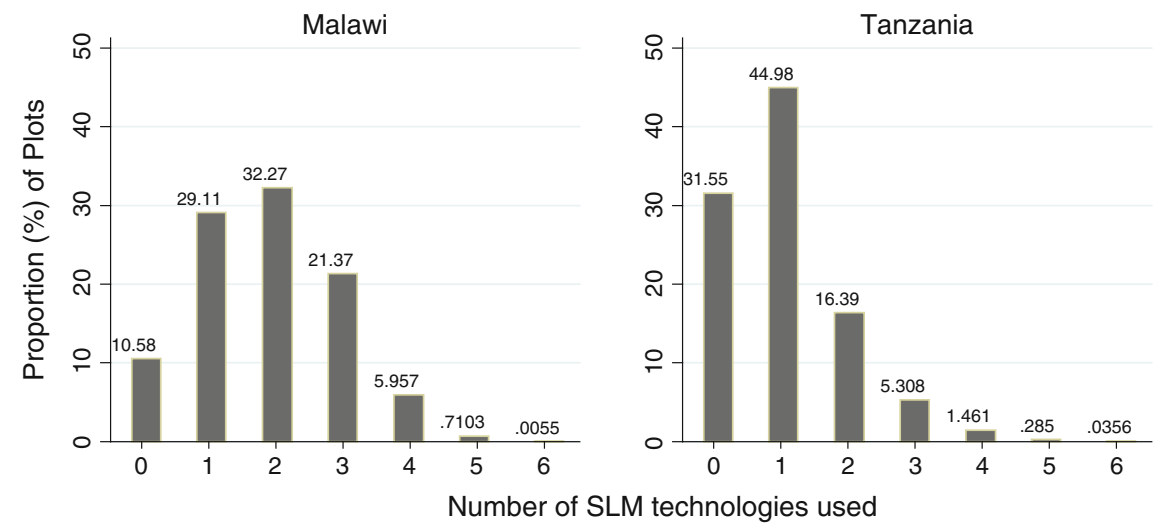

Fig. 20.5 The distribution of number SLM technologies used in Malawi and Tanzania. Source Authors' compilation 

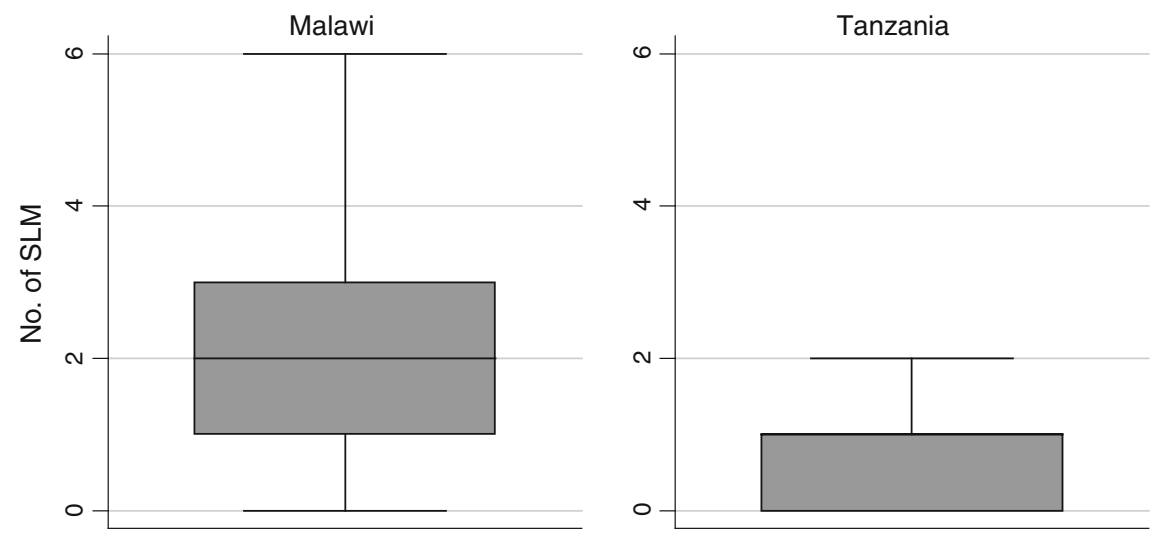

Fig. 20.6 The mean number of SLM technologies adopted by households, by country. Source Authors' compilation

and $16 \%$ in Malawi and Tanzania respectively. Fewer plots applied more than two SLM technologies simultaneously in one plot respectively in the two countries. Three SLM technologies were applied in about 21 and $5 \%$ in Malawi and Tanzania respectively while four SLM technologies were applied in about 6 and $2 \%$ in Malawi and Tanzania respectively. Even fewer plots applied 5 SLM technologies in the region; about 0.7 and $0.3 \%$ in Malawi and Tanzania respectively (Fig. 20.5).

Figure 20.6 presents the plot of the mean number of SLM technologies applied by country. The average number SLM technologies applied per plot were 1.7. This also varied across the countries; 1.9 in Malawi and 0.8 in Tanzania.

\section{Determinants of SLM Adoption: Logit Model}

The results of the logit regression models on the determinants of adoption of SLM technologies are presented in Table 20.5. An adopter was defined as an individual using at least one SLM technology. The assessment was carried out using plot level data. The logit models fit the data well (Table 20.5). All the F-test showed that the models were statistically significant at the $1 \%$ level. The Wald tests of the hypothesis that all regression coefficients in are jointly equal to zero were rejected in all the equations [(All-countries (joint model): Wald $\mathrm{Chi}^{2}(35)=2452.2, p$ value $=0.000),\left(\right.$ Malawi: Wald $\mathrm{Chi}^{2}(34)=1742.6, p$-value $\left.=0.000\right),($ Tanzania: Wald $\mathrm{Chi}^{2}(34)=239.5, p$-value $\left.=0.000\right)$ ]. The results (marginal effects) suggest that biophysical, demographic, plot-level, and socioeconomic characteristics significantly influence SLM adoption. We discuss significant factors for each country model in the subsequent section.

Results show that several biophysical, socioeconomic, demographic, institutional and regional characteristics dictate the adoption of SLM practices 
Table 20.5 Drivers of adoption of SLM practices in Eastern Africa: logit regression results

\begin{tabular}{|c|c|c|c|c|c|c|}
\hline \multirow[t]{2}{*}{ Variables } & \multicolumn{2}{|c|}{$\begin{array}{l}\text { Combined } \\
(\mathrm{n}=23,776)\end{array}$} & \multicolumn{2}{|c|}{$\begin{array}{l}\text { Malawi } \\
(\mathrm{n}=18,162)\end{array}$} & \multicolumn{2}{|l|}{$\begin{array}{l}\text { Tanzania } \\
(\mathrm{n}=5614)\end{array}$} \\
\hline & Coef. & Std. err. & Coef. & Std. err. & Coef. & Std. err. \\
\hline rainfall $(\log )$ & $0.481 * * *$ & 0.114 & $2.110 * * *$ & 0.203 & $-0.802 * * *$ & 0.155 \\
\hline rainfall $^{2}(\log )$ & 0.003 & 0.011 & -0.084 & 0.762 & -0.207 & 0.036 \\
\hline remperature (log) & 0.107 & 0.556 & $6.643 * * *$ & 1.030 & -0.025 & 0.719 \\
\hline temperature $^{2}(\log )$ & 0.000 & 0.103 & 0.000 & 0.120 & 0.000 & 0.004 \\
\hline temp\#rainfall (log) & 0.000 & 0.455 & 0.000 & 2.829 & 0.000 & 0.085 \\
\hline terrain_plateaus & $0.112 * *$ & 0.044 & $0.223 * * *$ & 0.056 & 0.020 & 0.074 \\
\hline terainr_hills & $0.168 * *$ & 0.085 & $0.687 * * *$ & 0.146 & -0.049 & 0.131 \\
\hline elevation & $0.001 * * *$ & 0.000 & $0.002 * * *$ & 0.000 & 0.000 & 0.000 \\
\hline warm_humid aez & $0.470 * * *$ & 0.055 & $0.936 * * *$ & 0.085 & $0.346 * *$ & 0.144 \\
\hline cool_arid aez & 0.076 & 0.084 & $0.295 * * *$ & 0.093 & 0.175 & 0.223 \\
\hline cool_humid aez & $0.173 * *$ & 0.083 & $0.570 * * *$ & 0.153 & $0.584 * * *$ & 0.163 \\
\hline age & -0.008 & 0.007 & -0.006 & 0.010 & -0.015 & 0.013 \\
\hline $\operatorname{age}^{2}$ & 0.000 & 0.000 & 0.000 & 0.000 & 0.000 & 0.000 \\
\hline sex & $-0.110 * *$ & 0.051 & $-0.111 *$ & 0.067 & -0.070 & 0.085 \\
\hline education & $0.133 * * *$ & 0.016 & $0.050 *$ & 0.027 & $0.031 *$ & 0.022 \\
\hline education $^{2}$ & 0.011 & 0.001 & -0.004 & 0.002 & 0.004 & 0.002 \\
\hline family_size & $0.046 * * *$ & 0.011 & $0.014 *$ & 0.019 & $0.032 * *$ & 0.013 \\
\hline plots_lope & $0.468 * * *$ & 0.042 & $0.565^{* * *}$ & 0.056 & $0.353 * * *$ & 0.068 \\
\hline tittledeed & $0.293 * * *$ & 0.044 & $0.204 * * *$ & 0.062 & $0.345 * * *$ & 0.111 \\
\hline sandy & -0.001 & 0.054 & 0.005 & 0.068 & -0.078 & 0.095 \\
\hline clay & $-1.043 * * *$ & 0.113 & $-1.998 * * *$ & 0.499 & -0.257 & 0.162 \\
\hline soil_quality & $-0.211 * * *$ & 0.071 & $-0.305 * * *$ & 0.089 & 0.179 & 0.132 \\
\hline plot_distance (log) & $-0.182 * * *$ & 0.028 & -0.077 & 0.065 & $0.068 *$ & 0.036 \\
\hline $\begin{array}{l}\text { market_distance } \\
(\log )\end{array}$ & $-0.638^{* *}$ & 0.018 & $-0.770 * * *$ & 0.024 & $-0.751 * * *$ & 0.046 \\
\hline extension & $0.137 *$ & 0.076 & $0.202 * * *$ & 0.299 & $0.140 * *$ & 0.089 \\
\hline plot_size & 0.002 & 0.005 & $0.340 * * *$ & 0.049 & $0.002 *$ & 0.004 \\
\hline group & $0.072 * *$ & 0.057 & $0.185^{* *}$ & 0.084 & $0.098 * *$ & 0.082 \\
\hline credit_access & $0.042 * *$ & 0.060 & $0.027 *$ & 0.074 & $0.075^{*}$ & 0.116 \\
\hline credit_amount (log) & 0.008 & 0.037 & $0.172 * * *$ & 0.051 & 0.084 & 0.065 \\
\hline assets $(\log )$ & $0.199 * * *$ & 0.015 & $0.165 * * *$ & 0.022 & $0.067 * * *$ & 0.023 \\
\hline irrigation & 0.167 & 0.188 & $-0.879^{*}$ & 0.254 & $0.472 *$ & 0.270 \\
\hline constant & -3.876 & 3.373 & $-52.556^{*}$ & 5.989 & 5.098 & 4.459 \\
\hline Tanzania & $0.144 * * *$ & 0.334 & & & & \\
\hline \multirow[t]{4}{*}{ Model characteristics } & \multicolumn{2}{|c|}{ No of obs. $=23,776$} & \multicolumn{2}{|c|}{ No. of obs. $=18,162$} & \multicolumn{2}{|c|}{ No. of obs. $=5614$} \\
\hline & \multicolumn{2}{|c|}{$\begin{array}{l}\mathrm{LR} \\
\mathrm{Chi}^{2}(35)=2452.2\end{array}$} & \multicolumn{2}{|c|}{$\operatorname{LR~Chi}^{2}(34)=1742.6$} & \multicolumn{2}{|c|}{$\operatorname{LR~Chi~}^{2}(34)=239.5$} \\
\hline & \multicolumn{2}{|c|}{ Prob $>$ chi $^{2}=0.000$} & \multicolumn{2}{|c|}{ Prob $>$ chi $^{2}=0.000$} & \multicolumn{2}{|c|}{ Prob $>\mathrm{chi}^{2}=0.000$} \\
\hline & \multicolumn{2}{|c|}{ Pseudo $\mathrm{R}^{2}=0.169$} & \multicolumn{2}{|c|}{ Pseudo $\mathrm{R}^{2}=0.187$} & \multicolumn{2}{|c|}{ Pseudo $\mathrm{R}^{2}=0.165$} \\
\hline
\end{tabular}

***, **, and *Denotes significance at 1,5 and $10 \%$ respectively

2 Describes mean values

Source Authors' compilation 
(Table 20.5). Among the proximate biophysical factors that significantly determine the probability of adopting SLM technology, we include temperature, rainfall and agro-ecological zonal characteristics. Temperature positively influences the probability of using SLM technologies in Malawi. For every $1 \%$ increase in mean annual temperature $\left({ }^{\circ} \mathrm{C} * 10\right)$, we expect $6.6 \%$, increase in probability of SLM adoption holding other factors constant.

Rainfall on the other hand showed varied effect on the probability of adopting SLM technologies; positive in Malawi and the joint model but negative in Tanzania. For every $1 \%$ increase in mean annual rainfall, we expect 0.48 and $2.1 \%$ increase in probability of adopting SLM technology in the joint model and in Malawi respectively, but a decrease of $0.8 \%$ in Tanzania holding other factors constant. The interaction between rainfall and temperature did not yield any significant effects.

Our results also suggest that terrain is critical in determining SLM adoption in the case study countries. While taking lowlands as the base terrain, results show that SLM is more likely to occur in both the plateaus and the hilly terrains in both Malawi and in the joint model but insignificant in Tanzania. The probability of SLM adoption is 22.3 and $11.2 \%$ more for plots located in the plateaus of Malawi and in the joint model respectively, ceteris paribus. Similarly, SLM adoption is 68.7 and $16.8 \%$ more likely to be adopted in the hills of Malawi and the combined model holding other factors constant.

The adoption of SLM technologies is also significantly influenced by such household-level variables as sex and education level of the household head, and family size. Male-headed households are less likely to adopt SLM technologies by about $11 \%$ in Malawi and also by about $10 \%$ in the joint model than their female counterparts, holding other factors constant. Education and the abundance of labor supply through larger bigger family size positively influence the adoption of SLM technologies both in Malawi and Tanzania and in the joint model. For instance increase in education by 1 year of formal learning increases the probability of SLM adoption by about 5 and $3 \%$ in Malawi and Tanzania respectively, ceteris paribus.

We also assessed the effect of plot level characteristics on the adoption of SLM technologies. Plots with steeper slopes have a positive relationship with the adoption of SLM technologies in all cases. $1 \%$ increase in the slope of the plot increases SLM adoption by about 56.5 and $35.3 \%$ in Malawi and Tanzania respectively. Similarly secure land tenure through ownership of title deed positively influences the adoption of SLM technologies.

Holding other factors constant, ownership of title deed increased the probability of SLM adoption by about 20 and $35 \%$ in Malawi and Tanzania respectively. Market accessed or proximity to markets (shown by distance to the market from the plot) has negative significant influence on the probability of SLM adoption in Malawi and Tanzania and in the joint models. One kilometer increase in distance to market reduced the probability of SLM adoption by $0.64,0.77$ and $0.75 \%$ in the joint model, Malawi and Tanzania respectively, holding other factors constant. 
Important socio-economic variables including access to agricultural extension services and credit access are also significant determinants of SLM technologies. Access to extension increased probability SLM adoption by 13.7, 20.2 and $14 \%$ in the joint model, Malawi and Tanzania respectively, while membership in farmer organizations increased probability of SLM adoption by 7.2, 18.5 and $9.8 \%$ in the joint model, Malawi and Tanzania respectively, ceteris paribus. Further, credit access increased probability LM adoption by 7.2, 18.5 and $9.8 \%$ in the joint model, Malawi and Tanzania respectively, ceteris paribus. The adoption of SLM technologies was significantly higher in Tanzania by about $14 \%$ than in Malawi.

\section{Determinants of Number of SLM Practices Adopted: Poisson Regression}

Results of the Poisson regression on the determinants of the number of SLM technologies used by households are presented in Table 20.6. The assessment is done at plot level in each of the case study countries and a joint model is also estimated for all the countries. The models fit the data well. All the models are statistically significant at $1 \%$ [(All-countries (joint model): Wald $\mathrm{Chi}^{2}(35)=2335.6, p$-value $=0.000$ ), (Malawi: Wald $\mathrm{Chi}^{2}(34)=1649.2, p$-value $\left.=0.000\right),\left(\right.$ Tanzania: Wald $\mathrm{Chi}^{2}$ $(34)=349.1, p$-value $=0.000)]$. There was no evidence of dispersion (over-dispersion and under-dispersion). We estimated the corresponding negative binomial regressions and all the likelihood ratio tests (comparing the negative binomial model to the Poisson model) were not statistically significant—suggesting that the Poisson model was best fit for our study assessments.

Results (Table 20.6) show that biophysical, plot-level, demographic, socio-economic and regional factors significantly determine the number of SLM technologies adopted. Among the proximate biophysical factors that significantly determine the number of SLM technologies adopted include temperature, rainfall, elevation and agro-ecological zonal characteristics. For example, a $1 \%$ increase in temperature $\left({ }^{\circ} \mathrm{C} * 10\right)$ increases the number of SLM technologies by $0.3 \%$ in Malawi but reduces number of SLM technologies by $0.5 \%$ in Tanzania holding other factors constant. Similarly, a $1 \%$ increase in rainfall increased the number of SLM technologies adopted by $0.3 \%$ in Malawi but reduces the number of SLM technologies by $0.2 \%$ in Tanzania ceteris paribus. Like in the probability of SLM adoption technologies, the interaction between rainfall and temperature did not yield any significant effects. Our results also suggest that terrain is an important determinant of the number of SLM technologies adopted in Malawi. Lowlands were selected as the base terrain. Results show that the number of SLM technologies adopted was about 10 and $13 \%$ more in Malawian plateaus and hills respectively, ceteris paribus. 
Table 20.6 Drivers of number of SLM technologies adopted: poisson regression

\begin{tabular}{|c|c|c|c|c|c|c|}
\hline \multirow[t]{2}{*}{ Variables } & \multicolumn{2}{|c|}{ All $(\mathrm{n}=23,776)$} & \multicolumn{2}{|c|}{ Malawi $(\mathrm{n}=18,162)$} & \multicolumn{2}{|c|}{ Tanzania $(\mathrm{n}=5614)$} \\
\hline & Coef. & Std. Err. & Coef. & Std. Err. & Coef. & Std. Err. \\
\hline rainfall $(\log )$ & $0.312 * * *$ & 0.023 & $0.423 * * *$ & 0.025 & $-0.224 * * *$ & 0.061 \\
\hline rainfall $^{2}(\log )$ & 0.000 & 0.031 & 0.000 & 0.082 & 0.007 & 0.011 \\
\hline temperature (log) & $-0.389 * * *$ & 0.121 & $0.280 *$ & 0.149 & $-0.531 * *$ & 0.255 \\
\hline temperature ${ }^{2}(\log )$ & -0.243 & 0.672 & -0.137 & 0.327 & -0.536 & 0.863 \\
\hline tempe\#rainfall (log) & 0.118 & 0.002 & 0.009 & 0.001 & 0.022 & 0.000 \\
\hline terrain_plateaus & $0.080 * * *$ & 0.010 & $0.100 * * *$ & 0.010 & 0.003 & 0.029 \\
\hline terainr_hills & $0.078 * * *$ & 0.015 & $0.129 * * *$ & 0.015 & -0.073 & 0.048 \\
\hline elevation & $0.000 *$ & 0.000 & $0.000 * * *$ & 0.000 & $0.000 * *$ & 0.000 \\
\hline warm_humid aez & $0.092 * * *$ & 0.012 & $0.148 * * *$ & 0.013 & -0.030 & 0.060 \\
\hline cool_arid aez & $-0.063 * * *$ & 0.016 & -0.016 & 0.016 & $0.151^{*}$ & 0.084 \\
\hline cool_humid aez & 0.013 & 0.017 & $0.070 * * *$ & 0.018 & 0.106 & 0.065 \\
\hline age & 0.002 & 0.001 & 0.002 & 0.002 & 0.006 & 0.005 \\
\hline $\operatorname{age}^{2}$ & 0.000 & 0.000 & 0.000 & 0.000 & 0.000 & 0.000 \\
\hline $\operatorname{sex}($ male $=1)$ & $-0.034 * * *$ & 0.011 & $-0.025 * *$ & 0.011 & -0.002 & 0.033 \\
\hline education & $0.129 * * *$ & 0.003 & $0.111 * * *$ & 0.004 & $0.172 * *$ & 0.008 \\
\hline education $^{2}$ & 0.002 & 0.000 & -0.001 & 0.000 & 0.002 & 0.001 \\
\hline family_size & $-0.010 * * *$ & 0.002 & -0.001 & 0.003 & $-0.016^{* *}$ & 0.005 \\
\hline plots_lope & $0.151 * * *$ & 0.008 & $0.148 * * *$ & 0.008 & $0.146^{* * *}$ & 0.025 \\
\hline tittle_deed $(1=$ yes $)$ & $0.233 * * *$ & 0.011 & $0.210 * * *$ & 0.011 & $0.235 * * *$ & 0.038 \\
\hline sandy $(1=$ yes $)$ & -0.016 & 0.011 & $-0.028 * *$ & 0.012 & -0.011 & 0.037 \\
\hline clay $(1=$ yes $)$ & $-0.596^{*}$ & 0.032 & -0.500 & 0.172 & -0.272 & 0.064 \\
\hline soil_quality & $-0.041 *$ & 0.014 & -0.035 & 0.014 & 0.113 & 0.053 \\
\hline plot_distance (log) & -0.111 & 0.009 & $-0.056^{*}$ & 0.012 & -0.004 & 0.014 \\
\hline $\begin{array}{l}\text { market_distance } \\
(\log )\end{array}$ & $-0.112 * * *$ & 0.004 & $-0.142 * * *$ & 0.004 & $-0.054 * * *$ & 0.018 \\
\hline extension $(1=$ yes $)$ & $0.120 * *$ & 0.019 & $0.159 * * *$ & 0.019 & $0.174 * *$ & 0.035 \\
\hline plot_size & $0.002 *$ & 0.001 & $0.023 * * *$ & 0.005 & $0.002 * *$ & 0.001 \\
\hline group & $0.036 * * *$ & 0.012 & $0.056 * * *$ & 0.012 & $0.060 * *$ & 0.030 \\
\hline $\begin{array}{l}\text { credit_access } \\
(1=\text { yes })\end{array}$ & $0.029 * *$ & 0.012 & $0.010 * *$ & 0.012 & $0.045^{* * *}$ & 0.040 \\
\hline credit_amount (log) & $0.014 *$ & 0.008 & $0.018 * *$ & 0.008 & $0.055^{* *}$ & 0.026 \\
\hline assets $(\log )$ & $0.246 * * *$ & 0.003 & $0.428 * * *$ & 0.004 & $0.830 * * *$ & 0.009 \\
\hline irrigation $(1=$ yes $)$ & -0.030 & 0.055 & $0.198^{*}$ & 0.076 & $0.192 *$ & 0.086 \\
\hline constant & 0.050 & 0.722 & $4.576^{* * *}$ & 0.858 & $3.504 * *$ & 1.634 \\
\hline Malawi & $-0.071 * * *$ & 0.029 & - & & & \\
\hline \multirow{4}{*}{$\begin{array}{l}\text { Model } \\
\text { Characteristics }\end{array}$} & \multicolumn{2}{|c|}{ No of obs. $=23,776$} & \multicolumn{2}{|c|}{ No. of obs. $=18,162$} & \multicolumn{2}{|c|}{ No. of obs. $=5614$} \\
\hline & \multicolumn{2}{|c|}{$\operatorname{LR~Chi~}^{2}(34)=2335.6$} & \multicolumn{2}{|c|}{$\operatorname{LR~Chi}^{2}(34)=1649.2$} & \multicolumn{2}{|c|}{$\operatorname{LR~Chi}^{2}(36)=394.1$} \\
\hline & \multicolumn{2}{|c|}{ Prob $>$ chi $^{2}=0.0000$} & \multicolumn{2}{|c|}{ Prob $>\mathrm{chi}^{2}=0.0000$} & \multicolumn{2}{|c|}{ Prob $>$ chi $^{2}=0.0000$} \\
\hline & \multicolumn{2}{|c|}{ Pseudo $R^{2}=0.1697$} & \multicolumn{2}{|c|}{ Pseudo $\mathrm{R}^{2}=0.1874$} & \multicolumn{2}{|c|}{ Pseudo $\mathrm{R}^{2}=0.1657$} \\
\hline
\end{tabular}

***, **, and *Denotes significance at 1,5 and $10 \%$ respectively

2 Describes mean values

Source Authors' compilation 
The number of SLM technologies adopted is also significantly determined by such household-level variables as sex and education level of the household head and family size. Male-headed households are less likely to adopt SLM technologies by about $2.5 \%$ in Malawi and by about $3.4 \%$ in the joint model than their female counterparts, holding other factors constant. Education level of the household head positively influenced the number of SLM technologies adopted both in Malawi and Tanzania and in the joint model. A unit increase in education by 1 year of formal learning increases the number of SLM technologies adopted by about 12.9, 11.1 and $17.2 \%$ in the joint model, Malawi and Tanzania respectively, ceteris paribus. In contrast, an additional family member (in adult equivalent) reduced the number of SLM technologies adopted by about 1 and $1.6 \%$ in Tanzania and the joint model respectively, holding other factors constant.

The number of SLM technologies adopted is also significantly determined by such slope, tenure status, soil type, and market access from the plot. The number of SLM technologies adopted is positively related to slope of the plot. A $1 \%$ increase in the slope of the plot increases the number of SLM technologies adopted by about 15.5, 14.8 and $14.6 \%$ in joint model, Malawi and Tanzania respectively, ceteris paribus.

Similarly secure land tenure through ownership of title deed positively influences the number of SLM technologies adopted. Ownership of title deed increased the probability of number of SLM technologies adopted by about 23, 21 and $23 \%$ in the joint model, Malawi and Tanzania respectively ceteris paribus. Our assessment further shows that proximity to markets (distance to the market) from the plot has negative significant influence on the probability of SLM adoption in Malawi and Tanzania and in the joint models. One kilometer increase in distance to market reduced the probability of SLM adoption by $0.11,0.14$ and $0.05 \%$ in the joint model, Malawi and Tanzania respectively, holding other factors constant.

Our results further show that socio-economic variables including access to agricultural extension services, access to credit services and household assets also determine the number of SLM technologies adopted. Access to extension increased the number of SLM technologies adopted by 12,16 and $17 \%$ in the joint model, Malawi and Tanzania respectively, while membership in farmer organizations increased the number of SLM technologies adopted by 3.6, 5.6 and $6 \%$ in the joint model, Malawi and Tanzania respectively, ceteris paribus. Further, credit access increased number of SLM technologies adopted by $2.9,1$ and $4.5 \%$ in the joint model, Malawi and Tanzania respectively, ceteris paribus. A $1 \%$ increase in household assets increased the number of SLM technologies adopted by $0.25,0.43$ and $0.83 \%$ in the joint model, Malawi and Tanzania respectively, ceteris paribus. The adoption of SLM technologies was significantly higher in Malawi by about $7.1 \%$ than in Tanzania.

Robust checks show no evidence of multicollinearity, heteroscedasticity and omitted variables. Ramsey RESET test (ovitest) was not significant, showing no evidence of omitted variable, while the Breusch-Pagan/Cook-Weisberg test (hettest) showed no evidence of heteroscedasticity. We report robust standard errors. Further, the VIF test was less than 10, showing no evidence of multicollinearity. 


\section{Cost of Action and Inaction Against Land Degradation Due to $L U C C$}

The results of cost of action and costs of inaction against land degradation in Malawi and Tanzania are discussed in this section. In Malawi, results show that the average annual cost of land degradation during 2000-2009 periods was about 244 million USD (Table 20.7). Only about 153 million USD (62\%) of this cost represent the provisional ecosystem services. The other (about $38 \%$ ) represents the supporting and regulatory and cultural ecosystem services. Most of these costs were experienced in Mangochi (27 million USD), Nkhata Bay (24 million USD), and Nkhotakota district (20 million USD). Priority action is thus needed in these regions.

The costs of action over a 30-year horizon were about 4.1 billion USD, as opposed to inaction costs of about 15.6 billion USD if nothing is done over the same time period (30 years). Similarly, over a shorter time period of 6 years, the cost of action sums to about 4 billion USD as opposed to of inaction of about 11.5 billion USD. This implies that the costs of action against land degradation are about 4.3 times lower than the costs of inaction over the 30 year horizon. The implications is that; each dollar spent on addressing land degradation is likely to yield about 4.3 dollars of returns.

In Tanzania, results show that the annual cost of land degradation between 2000 and 2009 periods was about 2.3 billion USD (Table 20.8). Only about 1.3 billion USD (57\%) of this cost of land degradation represent the provisional ecosystem services. The other (about $43 \%$ ) represents the supporting and regulatory and cultural ecosystem services. Most of these costs were experienced in Morogoro region (297 million USD), Ruvuma region (214 million USD), and Rukwa region (193 million USD). These areas can be considered areas where priority action is needed. The results further show the costs of action against land degradation in a 30-year horizon is about 36.3 billion USD but the resulting losses (costs) may equal almost 138.8 billion USD during the same period if nothing is done. Similarly, over a shorter time period of 6 years, the cost of action sums to about 36.2 billion USD as opposed to costs of inaction of about 102.6 billion USD. This suggests that the costs of action against land degradation are 3.8 times lower than the costs of inaction over the 30 year horizon. For every dollar spent to address land degradation, the returns are about 3.8 dollars. Taking action against land degradation in both short and long-term periods is thus more favorable than inaction.

\section{Cost of Land Degradation Due to Use of Land Degrading Practices on Cropland}

Table 20.9 shows the simulated results of rain-fed maize and wheat and irrigated rice yields under business-as-usual and ISFM scenarios for a period of forty years. 


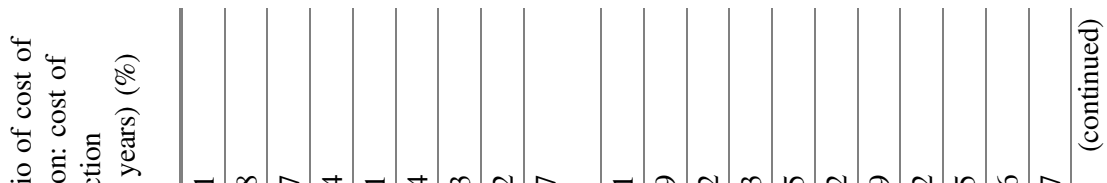

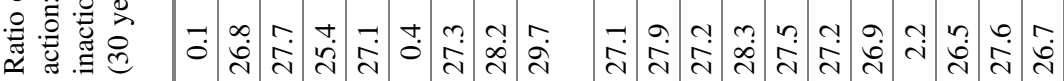

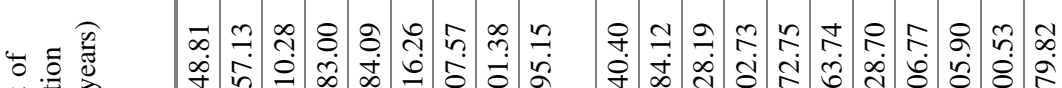

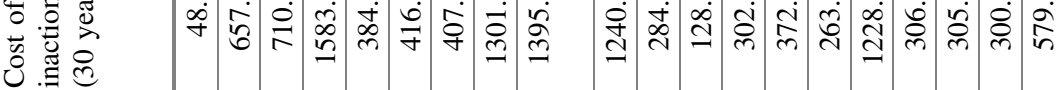

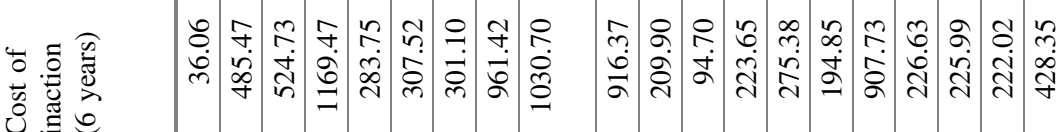

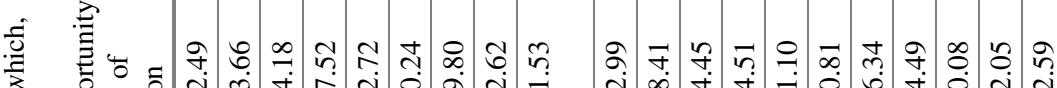

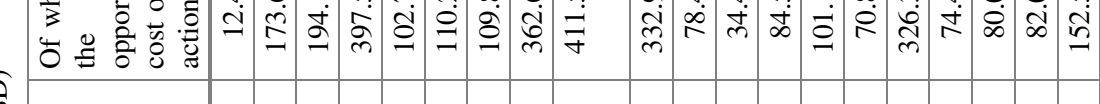

\begin{tabular}{|c|c|c|c|c|c|c|c|c|c|c|c|c|c|c|c|c|c|c|c|}
\hline 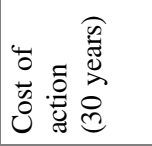 & $\stackrel{+}{0}$ & $\begin{array}{l} \pm \\
0 \\
\stackrel{0}{0} \\
\end{array}$ & 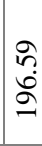 & 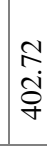 & $\stackrel{n}{ \pm}$ & $\stackrel{\infty}{\stackrel{\infty}{-}}$ & $\stackrel{ユ}{ユ}$ & $\frac{\Im}{\pi}$ & 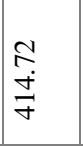 & 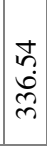 & $\underset{\stackrel{9}{+}}{\stackrel{9}{R}}$ & $\begin{array}{l}\vec{\sigma} \\
\dot{m}\end{array}$ & 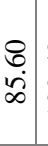 & 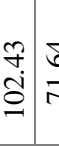 & & 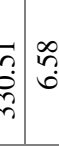 & $\frac{n}{2}$ & $\begin{array}{l}\approx \\
\stackrel{i}{d} \\
\infty\end{array}$ & $\begin{array}{l}\vec{F} \\
\stackrel{+}{\Delta}\end{array}$ \\
\hline 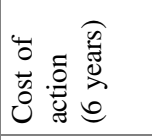 & $\stackrel{d}{\stackrel{d}{0}}$ & $\begin{array}{l}\mathfrak{g} \\
\stackrel{i}{ } \\
\underline{-}\end{array}$ & 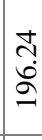 & $\frac{\circ}{\stackrel{\circ}{\circ}}$ & 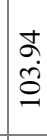 & $\stackrel{શ}{-}$ & $\underset{\Xi}{\Xi}$ & \begin{tabular}{l}
0 \\
\multirow{+}{*}{} \\
$\dot{0}$ \\
$\stackrel{0}{0}$
\end{tabular} & 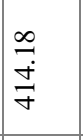 & $\begin{array}{l}\dot{\sigma} \\
\text { ભે } \\
\text { ले }\end{array}$ & $\begin{array}{l}\infty \\
\stackrel{1}{1} \\
2\end{array}$ & $\begin{array}{l}n \\
\infty \\
\dot{m} \\
\dot{m}\end{array}$ & 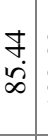 & 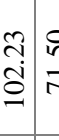 & 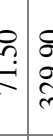 & 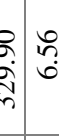 & $\begin{array}{l}\infty \\
\infty \\
\infty \\
\infty \\
\infty\end{array}$ & $\begin{array}{l}\vec{i} \\
i \\
\infty\end{array}$ & $\begin{array}{l}\text { ․ } \\
\text { in }\end{array}$ \\
\hline 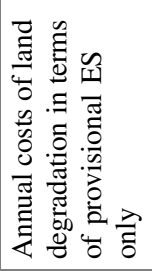 & n̊? & $\underset{\sim}{\stackrel{\sigma}{r}}$ & $\underset{\sim}{\infty}$ & $\begin{array}{l}\hat{a} \\
\dot{I}\end{array}$ & 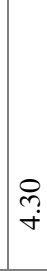 & $\underset{\sim}{\tilde{+}}$ & 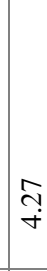 & $\begin{array}{l}0 \\
\ddot{g}\end{array}$ & กิ & $\underset{.}{\Xi}$ & $\begin{array}{l}\infty \\
\infty \\
i\end{array}$ & 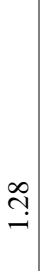 & $\frac{m}{m}$. & $\begin{array}{ll}8 & 5 \\
+ & 1\end{array}$ & 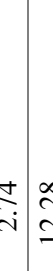 & 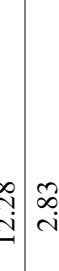 & $\begin{array}{l}n \\
\dot{n} \\
\dot{r}\end{array}$ & $\underset{i}{i}$ & $\overbrace{0}$ \\
\hline 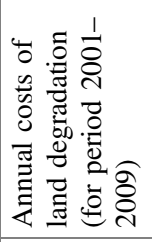 & $\frac{n}{o}$ & $\hat{\alpha}$ & $\stackrel{0}{0}$ & ָ̊. & ñ. & $\overrightarrow{0}$ & กิ & $\begin{array}{l}\mathbb{J} \\
\stackrel{0}{0}\end{array}$ & $\begin{array}{l}\infty \\
\stackrel{\infty}{\sim} \\
\stackrel{\sim}{\sim}\end{array}$ & $\begin{array}{l}\text { aे } \\
\text { a }\end{array}$ & $\begin{array}{l}\tilde{I} \\
\dot{\sim}\end{array}$ & $\stackrel{\Re}{-}$ & $\begin{array}{c}\infty \\
\stackrel{\infty}{+} \\
\sim\end{array}$ & 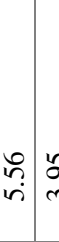 & & 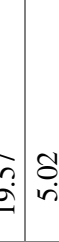 & $\begin{array}{l}\stackrel{\bullet}{0} \\
\dot{f}\end{array}$ & $\begin{array}{l}\hat{b} \\
\stackrel{+}{+}\end{array}$ & $\underset{\infty}{\infty}$ \\
\hline 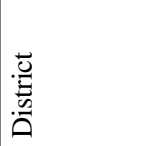 & $\frac{\frac{\tilde{y}}{\sigma}}{\frac{\pi}{\widetilde{\omega}}}$ & $\begin{array}{l}0 \\
3 \\
00 \\
0 \\
: 3 \\
3\end{array}$ & 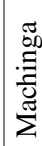 & $\begin{array}{l}3 \\
\overline{8} \\
0 \\
0 \\
\bar{\Xi} \\
\Sigma\end{array}$ & $:=\frac{1}{3}$ & 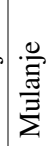 & $\mid \begin{array}{l}\mathbb{N} \\
\mathbb{N} \\
\sum_{\Sigma}^{3}\end{array}$ & 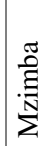 & $\begin{array}{ll}\frac{\pi}{\pi} \\
\frac{\pi}{z} \\
\text { 竞 }\end{array}$ & $\begin{array}{l}\frac{\pi}{0} \\
\frac{y}{\pi} \\
\frac{\tilde{\sigma}}{0} \\
\frac{\pi}{2} \\
z\end{array}$ & 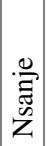 & 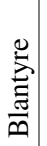 & $\begin{array}{l}\overrightarrow{\vec{d}} \\
\frac{\overrightarrow{0}}{\mathrm{Z}} \\
\bar{z}\end{array}$ & 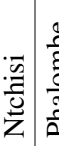 & 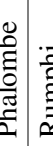 & 离 & 总 & $\begin{array}{l}\tilde{\sigma} \\
\stackrel{\Xi}{\Xi} \\
\text { N }\end{array}$ & 永 \\
\hline
\end{tabular}




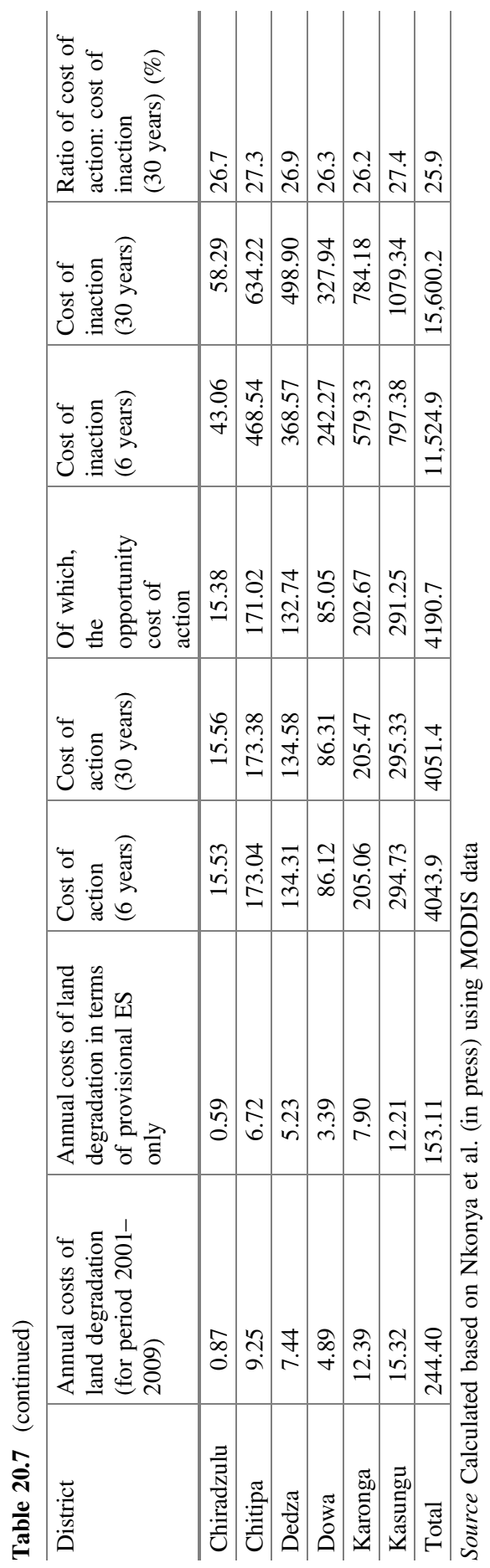




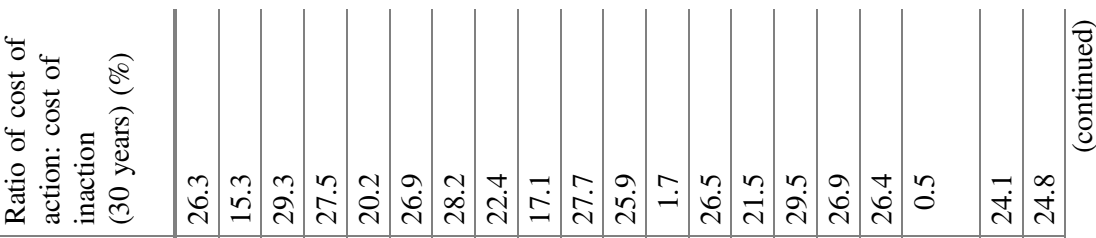

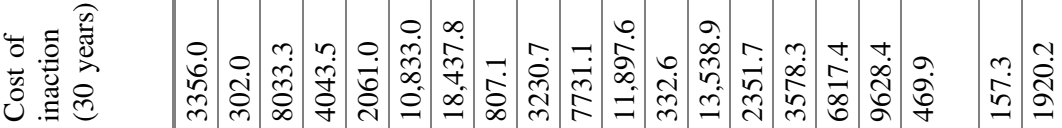

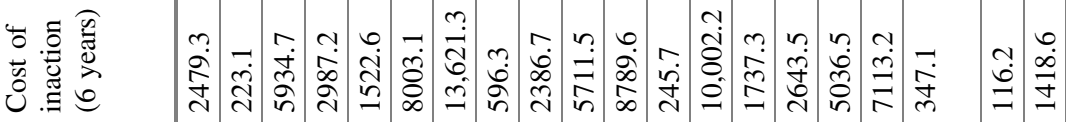

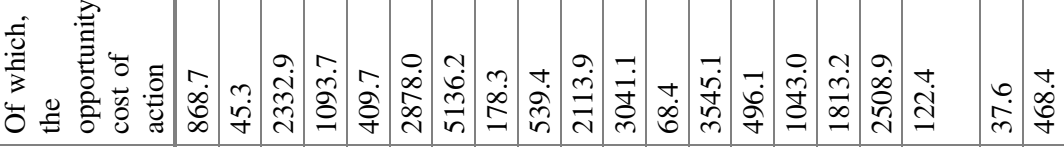

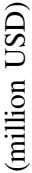

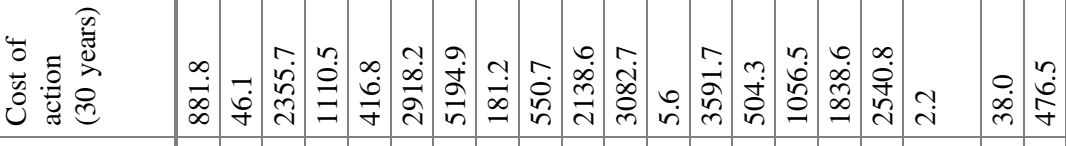

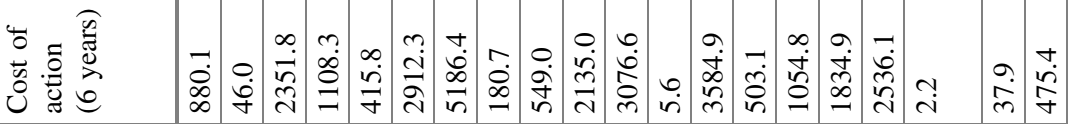

\begin{tabular}{|c|c|c|c|c|c|c|c|c|c|c|c|c|c|c|c|c|c|c|}
\hline 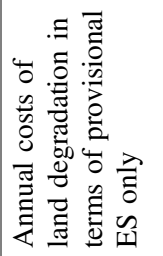 & ?̊. & $\stackrel{i}{i}$ & $\begin{array}{l}0 \\
\dot{b} \\
\ddot{b}\end{array}$ & $\stackrel{\sim}{\underset{f}{f}}$ & $\begin{array}{l}\infty \\
\dot{ \pm}\end{array}$ & $\begin{array}{l}\infty \\
\stackrel{\infty}{0} \\
=\end{array}$ & $\begin{array}{l}ت \\
\Xi\end{array}$ & $\stackrel{m}{n}$ & $\begin{array}{l}\stackrel{0}{+} \\
\dot{\sim}\end{array}$ & \begin{tabular}{l|l}
$\hat{\sigma}$ & $\vdots$
\end{tabular} & $\begin{array}{c}\mathbb{N} \\
\mathbb{N}\end{array}$ & $\hat{i} \begin{array}{l}n \\
\stackrel{f}{J}\end{array}$ & $\begin{array}{l}\infty \\
\stackrel{i}{i} \\
\stackrel{i}{|c|}\end{array}$ & $\stackrel{\nabla}{\grave{\lambda}}$ & $\stackrel{n}{n}$ & 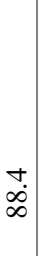 & $\vec{m}$ & $\grave{0}$ \\
\hline 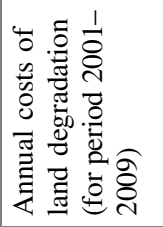 & 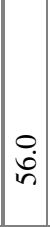 & $?$ & $\begin{array}{l}\hat{\mathrm{d}} \\
\mathrm{J}\end{array}$ & $\begin{array}{l}0 \\
\stackrel{0}{8} \\
8\end{array}$ & $\overrightarrow{\mathfrak{j}}$ & $\begin{array}{l}\hat{0} \\
\dot{0} \\
0\end{array}$ & $\stackrel{+}{\stackrel{\Delta}{\hat{~}}}$ & 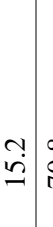 & 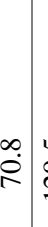 & 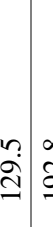 & 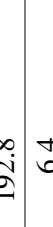 & 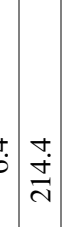 & $\overrightarrow{\dot{f}}$ & $\begin{array}{l}0 \\
\text { in } \\
\text { in }\end{array}$ & $\begin{array}{l}0 \\
\dot{8} \\
\dot{0}\end{array}$ & $\underset{\dot{\sigma}}{\underline{\sigma}}$ & $\stackrel{n}{a}$ & $\stackrel{\sim}{\sim}$ \\
\hline 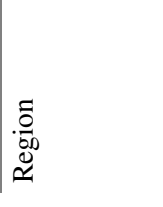 & $\frac{\frac{\pi}{5}}{3}$ & 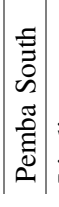 & $\mid$ & $\begin{array}{l}\stackrel{\pi}{\vec{\Xi}} \\
\stackrel{\Xi}{\Sigma}\end{array}$ & 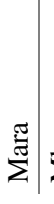 & $\begin{array}{l}\frac{\pi}{\vec{d}} \\
\dot{\Sigma} \\
\Sigma\end{array}$ & \begin{tabular}{c|c}
0 \\
0 \\
0 \\
0 \\
0 \\
\end{tabular} & $\sum_{\Sigma}^{\frac{\pi}{\tilde{J}}}$ & 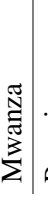 & $\begin{array}{l}3 \\
\vdots \\
0 \\
0\end{array}$ & 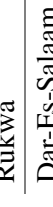 & 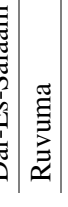 & 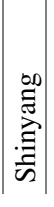 & $\begin{array}{l}\underset{\pi}{50} \\
\stackrel{\Xi}{n}\end{array}$ & 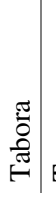 & 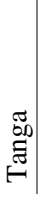 & 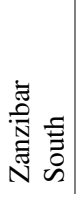 & 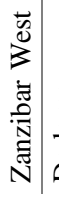 \\
\hline
\end{tabular}




\begin{tabular}{|c|c|c|c|c|c|c|c|}
\hline 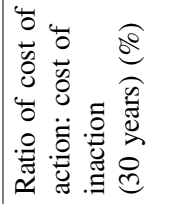 & $\stackrel{?}{\stackrel{?}{N}}$ & $\stackrel{\vec{d}}{\stackrel{d}{d}}$ & $\hat{0}$ & $\stackrel{t}{0}$ & $\stackrel{\sim}{\stackrel{\sim}{\sim}}$ & $\vec{i}$ & $\vec{i}$ \\
\hline 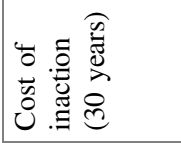 & 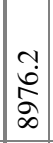 & $\begin{array}{l}\stackrel{1}{a} \\
\\
\bar{a}\end{array}$ & $\begin{array}{c}-1 \\
\vec{d} \\
\text { d. }\end{array}$ & $\frac{a}{m}$ & $\frac{\overrightarrow{0}}{\stackrel{0}{\infty}}$ & $\begin{array}{l}\vec{i} \\
\vec{i}\end{array}$ & $\begin{array}{l}2 \\
\infty \\
\infty \\
\infty \\
\infty\end{array}$ \\
\hline 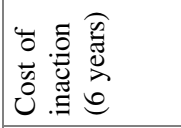 & $\frac{+}{\dot{\vec{g}}}$ & $\begin{array}{l}n \\
n \\
\tilde{n} \\
\tilde{b}\end{array}$ & 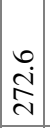 & $\begin{array}{r}\dot{v} \\
\vec{d} \\
\vec{\lambda}\end{array}$ & $\stackrel{\vec{m}}{\overrightarrow{0}}$ & 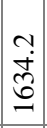 & 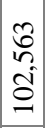 \\
\hline 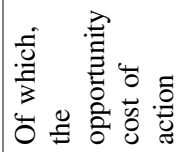 & $\frac{\stackrel{\sim}{d}}{\stackrel{\sim}{\sim}}$ & 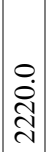 & 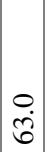 & 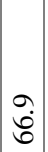 & $\begin{array}{l}\stackrel{+}{a} \\
\infty \\
\stackrel{\infty}{2}\end{array}$ & $\begin{array}{l}+ \\
\stackrel{2}{2} \\
\text { in }\end{array}$ & $\begin{array}{l}\hat{\sigma} \\
\delta \\
\delta \\
\delta\end{array}$ \\
\hline 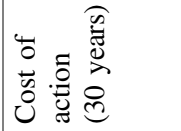 & 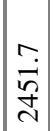 & 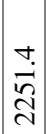 & $\vec{i}$ & $\stackrel{n}{n}$ & $\frac{\dot{\oplus}}{\stackrel{\sim}{\sigma}}$ & $\begin{array}{l}0 \\
\infty \\
\infty \\
i n\end{array}$ & $\begin{array}{l}0 \\
\\
\text { ñ } \\
\text { ñ }\end{array}$ \\
\hline 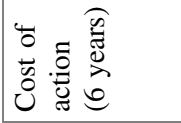 & $\underset{?}{\stackrel{?}{\sim}}$ & 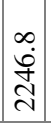 & $\bar{i}$ & $\stackrel{n}{n}$ & ڤి & $\begin{array}{l}n \\
\tilde{5} \\
i n\end{array}$ & 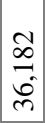 \\
\hline 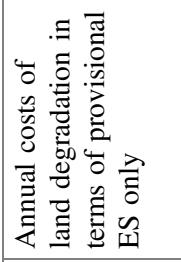 & $\begin{array}{l}\infty \\
\infty \\
\infty\end{array}$ & $\begin{array}{l}3 \\
\infty \\
\infty \\
\infty\end{array}$ & $\stackrel{\vec{i}}{\sim}$ & $\vec{i}$ & $\begin{array}{l}n \\
2 \\
\end{array}$ & $\begin{array}{l}n \\
\stackrel{2}{2}\end{array}$ & $\begin{array}{l}8 \\
0 \\
\infty \\
0 \\
-1\end{array}$ \\
\hline 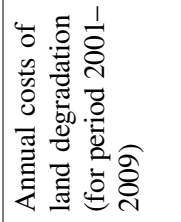 & $\begin{array}{l}0 \\
\stackrel{\dot{J}}{\Xi}\end{array}$ & $\begin{array}{l}n \\
\tilde{n} \\
n\end{array}$ & $\underset{\infty}{0}$ & \% & 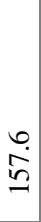 & $\begin{array}{l}\hat{b} \\
\dot{r}\end{array}$ & $\begin{array}{l}n \\
\dot{2} \\
\tilde{N} \\
\text { ते }\end{array}$ \\
\hline $\begin{array}{l}\widetilde{0} \\
\stackrel{0}{0 D} \\
\stackrel{0}{\simeq}\end{array}$ & $\begin{array}{c}\widetilde{0} \\
\stackrel{00}{\Xi} \\
\Xi\end{array}$ & 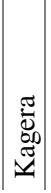 & 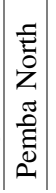 & 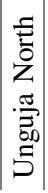 & 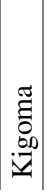 & 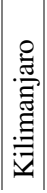 & 苟 \\
\hline
\end{tabular}


Table 20.9 Change in maize, rice and wheat yields under BAU and ISFM-DSSAT results

\begin{tabular}{|c|c|c|c|c|c|c|c|}
\hline \multirow[t]{3}{*}{ Country } & \multicolumn{2}{|l|}{ BAU } & \multicolumn{2}{|l|}{ ISFM } & \multicolumn{2}{|c|}{$\begin{array}{l}\text { Yield change } \\
(\%)\end{array}$} & \multirow{2}{*}{$\begin{array}{l}\text { Change due to } \\
\text { land degradation } \\
\text { Percent }\end{array}$} \\
\hline & Baseline & End-line & Baseline & End-line & BAU & ISFM & \\
\hline & \multicolumn{2}{|c|}{ Yield (tons/ha) } & \multicolumn{2}{|c|}{ Yield (tons/ha) } & \multicolumn{2}{|c|}{$\% \Delta y=\frac{y_{2}-y_{1}}{y_{1}} * 100$} & $\% D=\frac{y_{2}^{C}-y_{2}^{d}}{y_{2}^{d}} * 100$ \\
\hline \multicolumn{8}{|l|}{ Maize } \\
\hline Malawi & 2.37 & 1.57 & 2.51 & 1.92 & -33.5 & -23.3 & 22.0 \\
\hline Tanzania & 2.14 & 1.57 & 2.29 & 1.92 & -26.6 & -16.0 & 22.3 \\
\hline \multicolumn{8}{|l|}{ Rice } \\
\hline Malawi & 6.06 & 4.04 & 6.61 & 4.68 & -33.3 & -29.2 & 15.9 \\
\hline Tanzania & 5.88 & 4.17 & 6.16 & 4.51 & -29.0 & -26.8 & 8.0 \\
\hline \multicolumn{8}{|l|}{ Wheat } \\
\hline Malawi & 0.55 & 0.52 & 0.53 & 0.52 & -6.4 & -2.1 & 0.2 \\
\hline Tanzania & 0.66 & 0.64 & 0.67 & 0.68 & -3.5 & 0.6 & 5.9 \\
\hline
\end{tabular}

Note $\mathrm{y}_{1}=$ Baseline yield (average first 10 years); $\mathrm{y}_{2}=$ Yield end-line period (average last 10 years). $y_{2}^{c}=$ ISFM yield in the last 10 years; $y_{2}^{d}=$ BAU yield, last 10 years

Source Authors' compilation

The average maize yield in Malawi is 2.4 tons/ha (baseline) and 1.6 tons/ha (end-line) under the BAU scenario. This implies that the use of land degrading management practices on rain-fed maize leads to a $34 \%$ fall in yield compared to yield in the past 30 years. In Tanzania, the average maize yield under the BAU scenario is 2.1 tons/ha (baseline) and 1.6 tons/ha (end-line) - implying $34 \%$ fall in yield compared to yield in the past 30 years as a result of use of land-degrading management practices. Results further show that average maize yield are higher under ISFM - 2.5 tons/ha (baseline) and 1.9 tons/ha (end-line) periods in Ethiopia and 2.3 tons/ha (baseline) and 1.9 tons/ha (end-line) periods in Tanzania. This represents a decline of about 23 and $16 \%$ in Malawi and Tanzania respectively compared to yield in the past 30 years.

Irrigated rice yield declines under BAU scenario are $33 \%$ in Malawi and $29 \%$ in Tanzania and about $29 \%$ in Malawi and $27 \%$ in Tanzania under ISFM. On the other hand, wheat yield declines under BAU scenario are $6 \%$ in Malawi and $4 \%$ in Tanzania and about $2 \%$ in Malawi and $0.6 \%$ in Tanzania under ISFM.

On average the use of land degrading management practices on rain-fed maize leads to a $22 \%$ decline in yield as compared to yield the previous 30 years in each of the two countries. Similarly, analysis show that the use of land degrading management practices on irrigated rice leads to a $16 \%$ decline in yield in Malawi and $8 \%$ in Tanzania. Further, the use of land degrading management practices on rain-fed wheat leads to a $6 \%$ decline in yield Tanzania and about $0.2 \%$ decline in Malawi as compared to yield the previous 30 years.

The cost of land degradation for the three crops is about $\$ 277$ million per year (Table 20.10); \$114 million in Malawi and \$162 million in Tanzania. When these losses are expressed as percent of GDP, the two countries lose about $1.3 \%$ of the GDP annually as a result of cropland (maize, rice and wheat) degradation. At 
Table 20.10 Cost of soil fertility mining on static maize, rice and wheat cropland

\begin{tabular}{l|l|l|l}
\hline Country & $\begin{array}{l}\text { Cost of land degradation } \\
\text { (soil fertility mining) }\end{array}$ & $\begin{array}{l}\text { Cost as \% of } \\
\text { GDP }(\%)\end{array}$ & $\begin{array}{l}\text { Cost of all cropland } \\
\text { degradation as \% GDP }(\%)\end{array}$ \\
\cline { 2 - 4 } $2007 \$$ million & 3.1 & 7.4 \\
\hline Malawi & 114.09 & 1.0 & 2.3 \\
\hline Tanzania & 161.94 & 1.3 & 3.2 \\
\hline Total & 276.94 &
\end{tabular}

Source Authors' compilation

country level Malawi is the most severely affect by cropland degradation - loses about $3 \%$ of its GDP annually while in Tanzania the losses amount to about $1 \%$ of GDP. Statistics show that the three crops (maize, rice and wheat) account for about $42 \%$ of the cropland globally (Nkonya et al. in press). Assuming that the levels of degradation is comparable to that occurring on the three major crops, then the total cost of land degradation on cropland is about $3.2 \%$ of GDP in the two countriesranging from $2.3 \%$ in Tanzania to $7.4 \%$ in Malawi (Table 20.10).

The costs of land degradation due to soil fertility mining reported in Table 20.10 are conservative. Other aspects of land degradation common on a static biome (cropland) including soil erosion and salinity, and offside costs of pesticide use are not considered because of lack of data. The DSSAT data used in this study also assumes higher BAU fertilizer application rates - this reduces the actual costs of land degradation.

\section{Cost of Loss of Milk and Meat Production Due to Land Degradation of Rangelands}

Table 20.11 shows the simulated results of the costs of losses of milk, meat, and costs associated with weight loss of animals not slaughtered or sold associated with land degradation in rangelands. Computations were done by agro-ecological zone for an in-depth depiction and discussions of these costs. Chapter 8 of this volume presents a comprehensive analytical approach on how each of these components are computed.

Results shows that land degradation in grazing biomass had a significant impact on milk production both in Malawi and Tanzania. In Tanzania, the total costs of milk and meat production losses were about $\$ 53$ and $\$ 3.3$ respectively. The bigger proportion of milk and meat losses is experienced in the warm sub-humid (\$26 million), cool sub-humid (\$19 million) and cool semi-arid (\$9 million) agro-ecologies.

When the cost of weight loss of animals not slaughtered or sold is considered, the total costs of grassland degradation increases to about \$74 million in Tanzania. The bigger proportion of the total gross losses is experienced in the warm sub-humid (\$33 million), cool sub-humid (\$25 million) and cool semi-arid (\$12 million) agro-ecologies. 
Table 20.11 Annual cost of milk and meat production loss due to degradation of grazing biomass

\begin{tabular}{l|r|l|l|l}
\hline Agro-ecological zones & Milk & Meat & $\begin{array}{l}\text { Total loss } \\
\text { (milk and meat) }\end{array}$ & $\begin{array}{l}\text { Total gross loss_includes } \\
\text { weight loss of animals not } \\
\text { slaughtered/sold }\end{array}$ \\
\cline { 2 - 5 } & $2007 \$$ million \\
\hline Tanzania & 8.304 & 0.425 & 8.729 & 11.700 \\
\hline Tropic-cool semi-arid & \multicolumn{5}{l}{} \\
\hline Tropic-cool sub-humid & 17.862 & 0.837 & 18.699 & 25.166 \\
\hline Tropic-warm semi-arid & 2.797 & 0.131 & 2.928 & 3.941 \\
\hline Tropic-warm arid & 0.167 & 0.013 & 0.180 & 0.235 \\
\hline Tropic-warm sub-humid & 23.652 & 1.934 & 25.586 & 33.324 \\
\hline Total & 52.781 & 3.34 & 56.122 & 74.366 \\
\hline Malawi & & \multicolumn{5}{|l}{} \\
\hline Tropic-cool semi-arid & 0.138 & 0.008 & 0.146 & 0.200 \\
\hline Tropic-cool sub-humid & 0.183 & 0.034 & 0.217 & 0.265 \\
\hline Tropic-warm semi-arid & 1.128 & 0.09 & 1.218 & 1.634 \\
\hline Tropic-warm sub-humid & 0.106 & 0.009 & 0.114 & 0.153 \\
\hline Total & 1.555 & 0.141 & 1.696 & 2.253 \\
\hline
\end{tabular}

Source Authors' compilation

In Malawi, the total costs of milk is about $\$ 1.5$ million while the cost of meat production losses is about $\$ 0.14$ million. The biggest losses are experienced in the warm semi-arid (\$0.22 million), cool sub-humid (\$0.22 million) and cool semi-arid (\$0.15 million) agro-ecologies. The total gross loss - cost of milk, meant and cost of weight loss of animals not slaughtered or sold-in Malawi was about \$2.3 million. The bigger proportion of the total gross losses is consequently experienced in warm semi-arid (\$1.6 million), cool sub-humid (\$0.27 million) and cool semi-arid (\$0.2 million) agro-ecologies.

\section{Actions Taken to Address ES Loss and Enhance ES Improvement}

Given the above big losses as a result of land degradation, we present the results of the assessment of the perception of trend in value of ES for major land use types for eight local communities in Tanzania (Table 20.12). From the community perspective, results show that the ES value of cropland is decreasing in all districts except one (Mufindi). Similarly, the value of forest ES is all decreasing in all cases except in Mufindi district. On the other hand the trend in value of grassland is mixed. Two districts reported an increase (Sejeli and Zuzu communities), while two districts reported a decline (Dakawa and Mazingira).

The actions that the communities take to address loss of ES or enhance or maintain ES improvement are presented in Table 20.13. For example, in forest 
Table 20.12 Perceptions of trend in value of ecosystem services by biomes in Tanzania

\begin{tabular}{l|l|l|l|l|l}
\hline District & Village & $\begin{array}{l}\text { Trend of ES } \\
\text { value of } \\
\text { cropland }\end{array}$ & $\begin{array}{l}\text { Trend of ES } \\
\text { value of } \\
\text { forest }\end{array}$ & $\begin{array}{l}\text { Trend of ES } \\
\text { value } \\
\text { grassland }\end{array}$ & $\begin{array}{l}\text { Trend of ES } \\
\text { value } \\
\text { shrub-land }\end{array}$ \\
\hline Kilosa & Zombo & Decreasing & Decreasing & N/A & N/A \\
\hline Morogoro & Dakawa & Decreasing & Decreasing & Decreasing & N/A \\
\hline Mufindi & Mtili & Increasing & Increasing & N/A & N/A \\
\hline Kongwa & Sejeli & Decreasing & N/A & Increasing & Increasing \\
\hline Dodoma & Zuzu & Decreasing & N/A & Increasing & N/A \\
\hline Bahi & Maya & Decreasing & Decreasing & N/A & Decreasing \\
\hline Manyoni & Mamba & Decreasing & N/A & N/A & Decreasing \\
\hline Handeni & Mazingira & Decreasing & Decreasing & Decreasing & N/A \\
\hline
\end{tabular}

Source Authors' compilation

Table 20.13 Actions taken to address ES loss and enhance ES improvement in Tanzania

\begin{tabular}{|c|c|c|c|c|}
\hline District & Village & Actions for cropland & Actions for forest & $\begin{array}{l}\text { Actions for } \\
\text { grassland }\end{array}$ \\
\hline Kilosa & Zombo & $\begin{array}{l}\text { Use tractors to break } \\
\text { land, crop and fallow } \\
\text { rotations, fertilizer use }\end{array}$ & $\begin{array}{l}\text { Afforestation, bylaw } \\
\text { for protection of the } \\
\text { existing forest }\end{array}$ & \\
\hline Morogoro & Dakawa & $\begin{array}{l}\text { Use of inorganic } \\
\text { fertilizer, promotion of } \\
\text { SLM }\end{array}$ & $\begin{array}{l}\text { Strongly enforced } \\
\text { bylaws; fines for } \\
\text { illegal logging }\end{array}$ & $\begin{array}{l}\text { Area closure for } \\
\text { rehabilitation; } \\
\text { controlled grazing }\end{array}$ \\
\hline Mufindi & Mtili & $\begin{array}{l}\text { Use of inorganic } \\
\text { fertilizers }\end{array}$ & $\begin{array}{l}\text { Bylaw for protection } \\
\text { of the existing forest } \\
\text { - protected areas }\end{array}$ & \\
\hline Kongwa & Sejeli & $\begin{array}{l}\text { Leave land fallow, } \\
\text { mulching, crop } \\
\text { rotation }\end{array}$ & & $\begin{array}{l}\text { Protected areas; } \\
\text { Bylaws and } \\
\text { community fines } \\
\text { and sanctions }\end{array}$ \\
\hline Dodoma & Zuzu & $\begin{array}{l}\text { Organic manure } \\
\text { application }\end{array}$ & & $\begin{array}{l}\text { They burn dried } \\
\text { grasses that green } \\
\text { grass can re-grow }\end{array}$ \\
\hline Bahi & Maya & Apply organic manure & $\begin{array}{l}\text { Protected forest } \\
\text { Bylaw and } \\
\text { punishment (fine } \\
\text { imprisonment) }\end{array}$ & \\
\hline Manyoni & Mamba & $\begin{array}{l}\text { Apply organic manure } \\
\text { SLM practices }\end{array}$ & & \\
\hline Handeni & Mazingira & Use new seed varieties & $\begin{array}{l}\text { Development of } \\
\text { bylaws }\end{array}$ & \\
\hline
\end{tabular}

Source Authors' compilation 
biomes, some of the actions taken to address loss of ES or enhance ES improvement include; afforestation programs (Zombo community), bylaws to protect existing forests (Zombo, Dakawa, and Mtili villages). Some actions taken in grasslands include area closure and controlled grazing (in Dakawa village) to community sanctions for overgrazing in Sejeli village.

\section{Conclusions and Policy Implications}

Land degradation is increasingly becoming an important subject due to the increasing number of causes as well as its effects. Recent assessments show that land degradation affected 51 and $41 \%$ in Tanzania, Malawi respectively. The adoption of sustainable land management practices as well as the number of SLM technologies adopted is critical in addressing land degradation in Malawi and Tanzania. Securing land tenure and access to relevant agricultural information pertaining to SLM will play an important role in enhancing SLM adoption. This implies that policies and strategies that facilities use to secure land tenure is likely to incentivize investments in SLM in the long-run since benefits accrue over time. There is a need to improve the capacity of land users through education and extension as well as improve access to financial and social capital to enhance SLM uptake. Local institutions providing credit services, inputs such as seed and fertilizers, and extension services must not be ignored in the development policies. The important role of rainfall and agro-ecological classification on adoption of and number of SLM technologies adopted suggests the need for proper geographical planning and targeting of SLM practices by stakeholders.

Losses due to land degradation are substantial. The annual costs of land degradation due to LUCC between 2001 and 2009 period based on TEV framework amount to about $\$ 244$ million in Malawi and \$2.3 billion in Tanzania-representing about 6.8 and $13.7 \%$ of GDP in 2007 in Malawi and Tanzania, respectively. It is worthwhile to take action against land degradation. The TEV computation points to lower costs of action ( $\$ 4.05$ billion in Malawi and $\$ 36.3$ billion in Tanzania) as compared to costs of inaction $(\$ 15.6$ billion in Malawi and $\$ 138.8$ billion in Tanzania) by about 4.3 times and 3.8 times over a 30-year horizon in Malawi and Tanzania, respectively. This implies that for each dollar spent to rehabilitate/restore degraded lands, it returns about 4.3 dollars and 3.8 dollars in Malawi and Tanzania, respectively. The use of land degrading practices in croplands (maize, rice and wheat) resulted in losses amounting to $\$ 5.7$ million in Malawi and \$1.8 million in Tanzania- $0.2 \%$ of GDP in Malawi and $0.01 \%$ of GDP in Tanzania. These costs are, however, conservative. We consider only three crops, other aspects of land degradation common on a static biome (cropland) including soil erosion and salinity, and offside costs of pesticide use are not considered because of lack of data. The results further show that the of land degradation on static grazing biomass 
(loss of milk, meat and the cost of weight loss of animals not slaughtered or sold) amounted to \$74 million in Tanzania and \$2.3 million in Malawi.

Some of the local level initiatives taken by local communities address loss of ecosystem services or enhance/maintain ecosystem services improvement such as afforestation programs, enacting of bylaws to protect existing forests, area closures and controlled grazing, community sanctions for overgrazing, and use of ISFM in croplands ought to be out-scaled and backed by formal laws.

Open Access This chapter is distributed under the terms of the Creative Commons Attribution Noncommercial License, which permits any noncommercial use, distribution, and reproduction in any medium, provided the original author(s) and source are credited.

\section{References}

Akhtar-Schuster, M., Thomas, R. J., Stringer, L. C., Chasek, P., \& Seely, M. (2011). Improving the enabling environment to combat land degradation: Institutional, financial, legal and science-policy challenges and solutions. Land Degradation and Development, 22(2), 299-312.

Areal, F. J., Touza, J., McLeod, A., Dehnen-Schmutz, K., Perrings, C., Palmieri, M. G., \& Spence, N. J. (2008). Integrating drivers influencing the detection of plant pests carried in the international cut flower trade. Journal of Environmental Management, 89, 300-307.

Arslan, A., McCarthy, N., Lipper, L., Asfaw, S., \& Cattaneo, A. (2013). Adoption and intensity of adoption of conservation farming practices in Zambia. Agriculture, Ecosystems \& Environment, 187, 72-86.

Asfaw, S., Shiferaw, B., Simtowe, F., \& Lipper, L. (2012). Impact of modern agricultural technologies on smallholder welfare: Evidence from Tanzania and Ethiopia. Food Policy, 37 (3), 283-295.

Assey, P. (2007). Environment at the Heart of Tanzania's development: Lessons from Tanzania's National Strategy for Growth and Reduction of Poverty, MKUKUTA (No. 6). IIED.

Bamire, A. S., Fabiyi, Y. L., \& Manyong, V. M. (2002). Adoption pattern of fertiliser technology among farmers in the ecological zones of south-western Nigeria: A Tobit analysis. Crop and Pasture Science, 53(8), 901-910.

Barrett, C. B., Bezuneh, M., \& Aboud, A. (2001). Income diversification, poverty traps and policy shocks in Côte d'Ivoire and Kenya. Food Policy, 26(4), 367-384.

Bekele, W., \& Drake, L. (2003). Soil and water conservation decision behavior of subsistence farmers in the eastern highlands of Ethiopia: A case study of the Hunde-Lafto area. Ecological Economics, 46, 437-451.

Belay, M., \& Bewket, W. (2013). Farmers' livelihood assets and adoption of sustainable land management practices in north-western highlands of Ethiopia. International Journal of Environmental Studies, 70(2), 284-301.

Belay, K. T., Van Rompaey, A., Poesen, J., Van Bruyssel, S., Deckers, J., \& Amare, K. (2014). Spatial analysis of land cover changes in eastern Tigray (Ethiopia) from 1965 to 2007: Are there signs of a forest transition? Land Degrad. Dev. doi:10.1002/ldr.2275

Berk, R. (2007). Overdispersion and poisson regression ensemble methods for data analysis in the behavioral, social and economic sciences. pp. 1-24. http://www.udel.edu/soc/faculty/parker/ SOCI836_S08_files/Berk\%26MacDonald_JQCF.pdf

Bluffstone, R. A., \& Köhlin, G. (2011). Agricultural investments, Livelihoods and Sustainability in East African Agriculture. Oxford, UK: RFF Press/Earthscan.

Burger, K., \& Zaal, F. (Eds.). (2012). Sustainable land management in the tropics: Explaining the miracle. Farnham, Surrey, UK: Ashgate Publishing, Ltd. 
Chabala, L.M., Kuntashula, E., Hamukwala, P., Chishala, B.H., \& Phiri, E. (2012). Assessing the value of land and costs of land degradation in Zambia: First draft report. University of Zambia, the Global Mechanism United Nations Convention to Combat Desertification and the Stockholm Environment Institute. pp. 1-93. http://www.theoslo.net/wp-content/uploads/2012/ 04/EVS_Zambia_Final_Report_Feb2012_EDITED.pdf. Accessed 01 May 2015.

Chasek, P., Essahli, W., Akhtar-Schuster, M., Stringer, L. C., \& Thomas, R. (2011). Integrated land degradation monitoring and assessment: Horizontal knowledge management at the national and international levels. Land Degradation and Development, 22(2), 272-284.

Chinsinga, B. (2008). Reclaiming policy space: Lessons from Malawi's 2005/2006 fertilizer subsidy programme future agricultures. Brighton, UK: Institute of Development Studies.

D'Odorico, P., Bhattachan, A., Davis, K. F., Ravi, S., \& Runyan, C. W. (2013). Global desertification: Drivers and feedbacks. Advances in Water Resources, 51, 326-344.

de Fries, R. S., Rudel, T., Uriarte, M., \& Hansen, M. (2010). Deforestation driven by urban population growth and agricultural trade in the twenty-first century. Nature Geoscience, 3, $178-181$.

de Groote, H., \& Coulibaly, N. G. (1998). Gender and generation: an intra-household analysis on access to resources in Southern Mali. African Crop Science Journal, 6(1), 79-95.

Delgado, J. A., Groffman, P. M., Nearing, M. A., Goddard, T., Reicosky, D., Lal, R., et al. (2011). Conservation practices to mitigate and adapt to climate change. Journal of Soil and Water Conservation, 66(2011), 118-129.

Denning, G., Kabambe, P., Sanchez, P., Malik, A., Flor, R., Harawa, R., et al. (2009). Input subsidies to improve smallholder maize productivity in Malawi: Toward an African green revolution. PLoS Biology, 7(1), 2-10.

Deressa, T., Hassan, R.M., \& Ringler, C. (2009). Assessing household vulnerability to climate change. IFPRI discussion paper 00935. Intl Food Policy Res Inst. Washington D.C. USA.

Diacono, M., \& Montemurro, F. (2010). Long-term effects of organic amendments on soil fertility. A review. Agronomy for Sustainable Development, 30(2), 401-422.

Dimara, E., \& Skuras, D. (2003). Adoption of agricultural innovations as a two-stage partial observability process. Agricultural Economics, 28(3), 187-196.

Dorward, A., \& Chirwa, E. (2009). The agricultural input subsidy programme 2005 to 2008 : Further Analysis. Mimeo.

Dregne, H. E. (2002). Land degradation in the drylands. Arid land research and management, 16 (2), 99-132.

Ervin, C. A., \& Ervin, D. E. (1982). Factors affecting the use of soil conservation practices: Hypotheses, evidence, and policy implications. Land economics, pp. 277-292.

Eswaran, H., Lal, R., \& Reich, P. F. (2001). Land degradation: An overview. Responses to Land degradation, pp. 20-35.

Famoye, F., Wulu, J. T., \& Singh, K. P. (2005). On the generalized poisson regression model with an application to accident data. Journal of Data Science, 2(2004), 287-295.

FAO. (2007). Paying farmers for environmental services, state of food and agriculture 2007, Rome: FAO. Rome: Italy.

FAO. (2011). Sustainable land management in practice guidelines and best practices for Sub-Saharan Africa. Rome.

Feder, G., Just, R. E., \& Zilberman, D. (1985). Adoption of agricultural innovations in developing countries: A survey. Economic Development and Cultural Change, 33(2), 255-298.

Fentie, D., Fufa, B., \& Bekele, W. (2013). Determinants of the use of soil conservation technologies by smallholder farmers: The Case of Hulet Eju Enesie District, East Gojjam Zone, Ethiopia. Asian Journal of Agriculture and Food Sciences, 1(04). ISSN: 2321-1571.

Fisher, M., Chaudhury, M., \& McCusker, B. (2010). Do forests help rural households adapt to climate variability? Evidence from Southern Malawi. World Development, 38(9), 1241-1250.

Folberth, C., Yang, H., Gaiser, T., Abbaspour, K. C., \& Schulin, R. (2013). Modelling maize yield responses to improvement in nutrient, water and cultivar inputs in sub-Saharan Africa. Agricultural Systems, 119, 22-34. 
Gebremedhin, B., \& Swinton, S. M. (2003). Investment in soil conservation in northern Ethiopia: the role of land tenure security and public programs. Agricultural Economics, 29(1), 69-84.

Gebreselassie, K., De Groote, H., \& Friesen, D. (2013). Gender analysis and approaches to gender responsive extension to promote quality protein maize (QPM) in Ethiopia. In Invited paper presented at the 4th International Conference of the African Association of Agricultural Economists, 22-25 Sept 2013, Hammamet, Tunisia.

Genius, M., Koundouri, P., Nauges, C., \& Tzouvelekas, V. (2014). Information transmission in irrigation technology adoption and diffusion: Social learning, extension services, and spatial effects. American Journal of Agricultural Economics, 96(1), 328-344.

Ghadim, A. A. K., \& Pannell, D. J. (1999). A conceptual framework of adoption of an agricultural innovation. Agricultural Economics, 21(2), 145-154.

Ghadim, A. K. A., Pannell, D. J., \& Burton, M. P. (2005). Risk, uncertainty, and learning in adoption of a crop innovation. Agricultural Economics, 33(1), 1-9.

Gillespie, J., Kim, S., \& Paudel, K. (2007). Why don't producers adopt best management practices? An analysis of the beef cattle industry. Agricultural Economics, 36(1), 89-102.

Greene, W. H. (2012). Econometric analysis (7th ed.). Boston, USA: Prentice Hall.

Habron, G. B. (2004). Adoption of conservation practices by agricultural landowners in three Oregon watersheds. Journal of Soil and Water Conservation, 59(3), 109-115.

Harris, A., Carr, A. S., \& Dash, J. (2014). Remote sensing of vegetation cover dynamics and resilience across southern Africa. International Journal of Applied Earth Observation and Geoinformation, 28, 131-139.

Heckmann, M. (2014). Farmers, smelters and caravans: Two thousand years of land use and soil erosion in North Pare, NE Tanzania. Catena, 113, 187-201.

Hein, L., \& De Ridder, N. (2006). Desertification in the Sahel: a reinterpretation. Global Change Biology, 12(5), 751-758.

ELD Initiative. (2013). The rewards of investing in sustainable land management. Interim report for the economics of land degradation initiative: A global strategy for sustainable land management. Available at: www.eld-initiative.org/

Jansen, H. G. P., Pender, J., Damon, A., Wielemaker, W., \& Schipper, R. (2006). Policies for sustainable development in the hillside areas of Honduras: A quantitative livelihoods approach. Agricultural Economics, 34, 141-153.

Kabubo-Mariara, J. (2007). Land conservation and tenure security in Kenya: Boserup's hypothesis revisited. Ecological Economics, 64, 25-35.

Kassie, M., Jaleta, M., Shiferaw, B., Mmbando, F., \& Mekuria, M. (2013). Adoption of interrelated sustainable agricultural practices in smallholder systems: evidence from rural Tanzania. Technological Forecasting and Social Change, 80(3), 525-540.

Kassie, M., Shiferaw, B., \& Muricho, G. (2011). Agricultural technology, crop income, and poverty alleviation in Uganda. World Development, 39(10), 1784-1795.

Kazianga, H., \& Masters, W. A. (2002). Investing in soils: Field bunds and microcatchments in Burkina Faso. Environment and Development Economics, 7(03), 571-591.

Kiage, L. M. (2013). Perspectives on the assumed causes of land degradation in the rangelands of Sub-Saharan Africa. Progress in Physical Geography, 37(5), 664-684.

Kim, S., Gillespie, J. M., \& Paudel, K. P. (2005). The effect of socioeconomic factors on the adoption of best management practices in beef cattle production. Journal of Soil and Water Conservation, 60(3), 111-120.

Kirui, O. K., \& Mirzabaev, A. (2014). Economics of land degradation in Eastern Africa (No. 128). ZEF Working Paper Series. Center for Development Research (ZEF), University of Bonn, Germany.

Kirui, O. K., \& Njiraini, G. W. (2013). Determinants of agricultural commercialization among the rural poor: Role of ICT and Collective Action Initiatives and gender perspective in Kenya. In African Association of Agricultural Economists (AAAE) 2013 Fourth International Conference, 22-25 Sept 2013. Hammamet, Tunisia.

Lal, R. (1995). Erosion-crop productivity relationships for soils of Africa. Soil Science Society of America Journal, 59(3), 661-667. 
Lal, R., \& Stewart, B. A. (2010). Food security and soil quality. Advances in soil science. http:// library.wur.nl/WebQuery/clc/1945402. Accessed 30 May 2015.

Lambin, E. F., \& Geist, H. (Eds.). (2006). Land-use and land-cover change local processes and global impacts. Berlin: Springer.

Lambin, E. F., \& Meyfroidt, P. (2010). Land use transitions: Socio-ecological feedback versus socio-economic change. Land use policy, 27(2), 108-118.

Le, Q. B., Nkonya, E., \& Mirzabaev, A. (2014). Biomass productivity-based mapping of global land degradation hotspots. ZEF-discussion papers on development policy, 193.

Levy, S., \& Barahona, C. (2002). 2001-2002 targeted input programme. Lilongwe, Malawi: Main Report of the Evaluation Programme.

Ligonja, P. J., \& Shrestha, R. P. (2013). Soil erosion assessment in Kondoa Eroded area in Tanzania using universal soil loss equation, geographic information systems and socioeconomic approach. Land degradation and development. Wiley Online Library. doi:10.1002/ldr. 2215, online first.

Lin, R., \& Chen, C. (2014). Tillage, crop rotation, and nitrogen management strategies for wheat in central Montana. Agronomy Journal, 106(2), 475-485.

Lindner, R. K. (1987). Adoption and diffusion of technology: An overview. In ACIAR proceedings series.

Maddison, D. (2006). The perception of and adaptation to climate change in Africa. CEEPA. Discussion Paper No. 10. Centre for Environmental Economics and Policy in Africa. University of Pretoria, Pretoria, South Africa.

Marenya, P. P., \& Barrett, C. B. (2007). Household-level determinants of adoption of improved natural resources management practices among smallholder farmers in western Kenya. Food Policy, 32(4), 515-536.

Marenya, P., Nkonya, E., Xiong, W., Deustua, J., \& Kato, E. (2012). Which policy would work better for improved soil fertility management in sub-Saharan Africa, fertilizer subsidies or carbon credits? Agricultural Systems, 110, 162-172.

MEA (Millennium Ecosystem Assessment). (2005). Dryland Systems. In R. Hassan, R. Scholes, \& N. Ash (Eds.), Ecosystem and well-being: Current state and trends (pp. 623-662). Washington, DC: Island Press.

Minot, N., \& Benson, T. (2009). Fertilizer subsidies in Africa: Are vouchers the answer? (No. 60). International Food Policy Research Institute (IFPRI).

Morris, M., Valerie, A. K., Kopicki, Ron J., \& Byerlee, D. (2007). Fertilizer use in African agriculture: Lessons learned and good practice guidelines. Washington, D.C.: The World Bank.

Nakhumwa, T. O., \& Hassan, R. M. (2012). Optimal management of soil quality stocks and long-term consequences of land degradation for smallholder farmers in Malawi. Environmental \& Resource Economics, 52(3), 415-433.

Nkonya, E., Mirzabaev, A., \& von Braun, J. (in press) Economics of land degradation and improvement-A global assessment for sustainable development. Springer International Publishing. doi:10.1007/978-3-319-19168-3_20

Nkonya, E. M., Pender, J. L., Kaizzi, K. C., Kato, E., Mugarura, S., Ssali, H., \& Muwonge, J. (2008). Linkages between land management, land degradation, and poverty in Sub-Saharan Africa: The case of Uganda (No. 159). International Food Policy Research Institute (IFPRI).

Nkonya, E., Von Braun, J., Alisher, M., Bao Le, Q., Ho Young, K., Kirui, O., \& Edward, K. (2013). Economics of land degradation initiative: Methods and approach for global and national assessments. ZEF-discussion papers on development policy no. 183, Bonn, Germany.

Norris, E., \& Batie, S. (1987). Virginia farmers' soil conservation decisions: an application of Tobit analysis. Southern Journal of Agricultural Economics, 19(1), 89-97.

Pagiola, S. (1996). Price policy and returns to soil conservation in semi-arid Kenya. Environmental \& Resource Economics, 8(3), 225-271.

Park, T. A., \& Lohr, L. (2005). Organic pest management decisions: A systems approach to technology adoption. Agricultural Economics, 33(s3), 467-478. 
Pender, J., \& Gebremedhin, B. (2008). Determinants of agricultural and land management practices and impacts on crop production and household income in the highlands of Tigray, Ethiopia. Journal of African Economies, 17(3), 395-450.

Pender, J., Jagger, P., Nkonya, E., \& Sserunkuuma, D. (2004a). Development pathways and land management in Uganda. World Development, 32(5), 767-792.

Pender, J., Nkonya, E., Jagger, P., Sserunkuuma, D., \& Ssali, H. (2004b). Strategies to increase agricultural productivity and reduce land degradation: evidence from Uganda. Agricultural Economics, 31(2-3), 181-195.

Pender, J., Nkonya, E., Jagger, P., Sserunkuuma, D., \& Ssali, H. (2006). Strategies to increase agricultural productivity and reduce land degradation in Uganda: An econometric analysis. Strategies for sustainable land management in the east African Highlands. International Food Policy Research Institute, Washington, DC, USA, pp. 165-190.

Pingali, P., Schneider, K., \& Zurek, M. (2014). Poverty, agriculture and the environment: The case of Sub-Saharan Africa. In Marginality (pp. 151-168). Netherlands: Springer.

Prokopy, L. S., Floress, K., Klotthor-Weinkauf, D., \& Baumgart-Getz, A. (2008). Determinants of agricultural best management practice adoption: Evidence from the literature. Journal of Soil and Water Conservation, 63(5), 300-311.

Rademaekers, K., Eichler, L., Berg, J., Obersteiner, M., \& Havlik, P. (2010). Study on the evolution of some deforestation drivers and their potential impacts on the costs of an avoiding deforestation scheme. European Commission Directorate-General for environment. Rotterdam. The Netherlands.

Reed, M. S., Buenemann, M., Atlhopheng, J., Akhtar-Schuster, M., Bachmann, F., Bastin, et al. (2011). Cross-scale monitoring and assessment of land degradation and sustainable land management: A methodological framework for knowledge management. Land Degradation and Development, 22(2), 261-271.

Safriel, U. N., \& Adeel, Z. (2005). Dryland systems.|| In R. Hassan, R. Scholes \& N. Ash (Eds.), Ecosystems and human well-being: Current state and trends (Vol. 1, pp. 623-662).

Shakeel, S., Akhtar, S., \& Fatima, S. A. (2014). A review on the usage, suitability and efficiency of animal manures for soil fertility in developing countries. Continental Journal of Agronomy, 7(1).

Shiferaw, B., \& Holden, S. (1998). Resource degradation and adoption of land conservation technologies in the Ethiopian highlands: case study in Andit Tid. North Shewa. Agricultural Economics, 27(4), 739-752.

Shively, G. E. (2001). Agricultural change, rural labor markets, and forest clearing: An illustrative case from the Philippines. Land Economics, 77(2), 268-284.

Teklewold, H., Kassie, M., \& Shiferaw, B. (2013). Adoption of multiple sustainable agricultural practices in rural Ethiopia. Journal of Agricultural Economics, 64(3), 597-623.

Thierfelder, C., Chisui, J. L., Gama, M., Cheesman, S., Jere, Z. D., Bunderson, Trent, et al. (2013). Maize-based conservation agriculture systems in Malawi: Long-term trends in productivity. Field Crops Research, 142, 47-57.

Thompson, A., Kotoglou, K., \& Deepayan, B. R. (2009). Financing sources for sustainable land management. United Kingdom: Oxford Policy Management London.

Tiffen, M., Mortimore, M., \& Gichuki, F. (1994). More people, less erosion: Environmental recovery in Kenya. Overseas Development Institute, London: John Wiley \& Sons Ltd.

Triboi, E., \& Triboi-Blondel, A. M. (2014). Towards sustainable, self-supporting agriculture: Biological nitrogen factories as a key for future cropping systems. In Soil as world heritage (pp. 329-342). The Netherlands: Springer.

United Republic of Tanzania (URT). (2005). National strategy for growth and reduction of poverty, Vice Presidents' Office, June.

United Republic of Tanzania (URT). (2008). Progress in millennium development goals: Mid way assessment, December.

von Braun, J., Gerber, N., Mirzabaev, A., \& Nkonya, E. (2012). The economics of land degradation. An Issue Paper for Global Soil Week, 08-22 Nov 2012. Berlin, Germany. 
Voortman, R. L., Sonneveld, B. G., \& Keyzer, M. A. (2000). African land ecology: Opportunities and constraints for agricultural development. Center for International Development Working Paper 37. Harvard University, Cambridge, Mass., USA.

Wale, H. A., \& Dejenie, T. (2013). Dryland ecosystems: Their features, constraints, potentials and managements. Research Journal of Agricultural and Environmental Management, 2(10), 277-288.

Wasige, J. E., Groen, T. A., Smaling, E., \& Jetten, V. (2013). Monitoring basin-scale land cover changes in Kagera Basin of Lake Victoria using ancillary data and remote sensing. International Journal of Applied Earth Observation and Geoinformation, 21, 32-42.

Waters, C. M., Penman, T. D., Hacker, R. B., Law, B., Kavanagh, R. P., Lemckert, F., \& Alemseged, Y. (2013). Balancing trade-offs between biodiversity and production in the re-design of rangeland landscapes. The Rangeland Journal, 35(2), 143-154.

Winkelmann, R., \& Zimmermann, K. F. (1995). Recent developments in count data modelling: Theory and application. Journal of economic surveys, 9(1), 1-24.

World Bank (WB). (2010). Managing land in a changing climate: An operational perspective for Sub-Saharan Africa. Draft version Report No.: 54134-AFR. WB, Washington D.C.

Xiang, L., \& Lee, A. H. (2005). Sensitivity of test for overdispersion in poisson regression. Biometrical Journal, 47, 167-176.

Yirga, C. T. (2007). The dynamics of soil degradation and incentives for optimal management in Central Highlands of Ethiopia. Ph.D. Thesis, Department of Agricultural Economics, Extension and Rural Development. University of Pretoria, South Africa.

Yu, L., Hurley, T., Kliebenstein, J., \& Orazen, P. (2008). Testing for complementarity and substitutability among multiple technologies: The case of U.S. hog farms, working paper, no. 08026, Iowa State University, Department of Economics, Ames, IA, USA.

Zorya S. (2009). National agricultural input voucher scheme in Tanzania. In Presentation prepared for the Common Market for Eastern and Southern Africa workshop Input Market Development, 15-16 June, Livingstone, Zambia. 